\title{
THE DISGORGEMENT INTEREST IN CONTRACT LAW
}

\author{
Melvin A. Eisenberg*
}

\begin{abstract}
Restatement Second of Contracts provided that contract law serves to protect one or more of three interests: the expectation interest, the reliance interest, and the restitution interest. There is, however, a fourth interest that contract law should and does protect: the disgorgement interest, which is the promisee's interest in requiring the promisor to disgorge a gain that was made possible by the promisor's breach, but did not consist of a benefit conferred on the promisor by the promisee. It is not clear why Restatement Second excluded the disgorgement interest. Perhaps the drafters believed that this position was compelled by positive law. That proposition, however, would have been doubtful even when Restatement Second was published, and it is clearly wrong today: some appellate cases, and $a$ handful of trial court cases, have denied protection to the disgorgement interest, but a dozen or so American appellate cases, as well as cases decided by the highest courts of several other common law jurisdictions, have afforded such protection. Alternatively, the drafters of Restatement Second may have believed that the disgorgement interest should not be protected as a normative matter. That proposition also cannot be supported. On the contrary, there are strong efficiency reasons, as well as moral reasons, for protecting the disgorgement interest, because in certain categories of cases, protection of that interest in contract law is necessary to provide efficient incentives to the promisor, to effectuate contracts, or to prevent unjust enrichment. Of course, the disgorgement interest should not be protected in all cases in which a promise is legally enforceable, any more than the reliance interest, the restitution interest, or, for that matter, the expectation interest are protected in all cases. Rather, as in the case of those interests, the disgorgement interest should be protected when appropriate, and in certain categories of cases protection of the disgorgement interest is always appropriate.
\end{abstract}

* Koret Professor of Law, University of California at Berkeley; Stephen and Barbara Friedman Visiting Professor of Law, Columbia Law School. I thank Shawn Bayern, Brian Bix, Robert Cooter, Daniel Friedmann, Lance Jasper, Ariel Porat, and Joel Willard for their exceptionally helpful comments on earlier drafts. 


\section{TABLE OF CONTENTS}

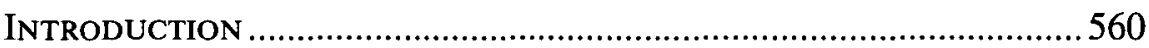

I. The Disgorgement InTEREST OUTSIDE CONTRACT LAW ...... 562

II. The Puzzle of Restatement Second..................................564

A. Positive-Law Considerations..........................................565

B. The Causation Arguments …............................................56 56

C. The Theory of Efficient Breach.........................................570

D. The Efficiency of Expectation Damages ............................. 577

III. Why Contract Law Should and Does Protect THE DISGORGEMENT INTEREST .........................................5 578

A. The General Argument .................................................. 578

B. Cases in which the Promisee Has Bargained for the Promisor's Gain from Breach...................................... 581

C. Disgorgement in Lieu of Specific Performance .................. 584

D. Disgorgement as a Surrogate for Expectation Damages...................................................... 587

E. Bargains Designed to Serve Interests Other

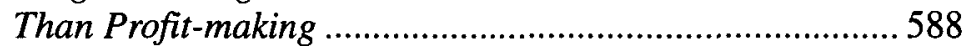

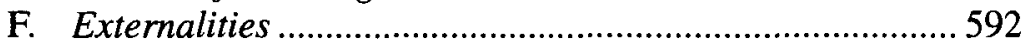

G. Disgorgement of Costs Saved by Breach......................... 592

IV. Why Don't We See More Disgorgement in

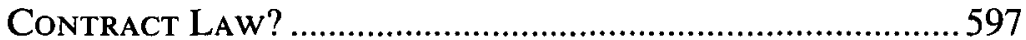

V. The Problem of APPortionment .......................................59

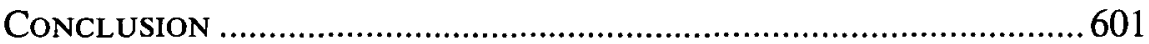

\section{INTRODUCTION}

Restatement Second of Contracts section 344 famously provides that judicial remedies in contract law serve to protect one or more of three interests of a promisee:

(a) his "expectation interest," which is his interest in having the benefit of his bargain by being put in as good a position as he would have been in had the contract been performed,

(b) his "reliance interest," which is his interest in being reimbursed for loss caused by reliance on the contract by being put in as good a position as he would have been in had the contract not been made, or

(c) his "restitution interest," which is his interest in having restored to him any benefit that he has conferred on the other party.'

There is a striking omission from this list: the disgorgement interest, which is the promisee's interest in requiring the promisor to disgorge a gain

1. Restatement (SeCOND) of Contracts $\$ 344$ (1981) [hereinafter Restatement SECOND] 
that was made possible by her breach but did not consist of a benefit conferred on her by the promisee. ${ }^{2}$

The disgorgement interest is the mirror image of the expectation interest. As stated in section 344(a), the expectation interest is the promisee's interest in being put in as good a position as he would have been in if the contract had been performed. Accordingly, perfect expectation damages would make the promisee indifferent between receiving performance, on the one hand, and receiving damages, on the other. In contrast, as Robert Cooter and Thomas Ulen have pointed out, disgorgement places the promisor in the position that she would have been in had the contract had been performed. Accordingly, perfect disgorgement would make the promisor indifferent between performing, on the one hand, and paying damages, on the other:

When disgorgement is perfect, the injurer is indifferent between doing right, on the one hand, or doing wrong and paying disgorgement damages, on the other hand. Thus, perfect disgorgement is identical to perfect compensation, with the roles of injurer and victim reversed. The injurer achieves no gain from the wrongdoing net of perfect disgorgement damages, just as the victim suffers no harm from the injury net of perfectly compensatory damages. ${ }^{3}$

The omission of the disgorgement interest in section 344 was plainly deliberate. For one thing, the section is written as an exclusive catalog. For another, shortly after publication of Restatement Second, Allen Farnsworth, the Reporter for much of the Restatement, including section 344, wrote a leading article entitled Your Loss or My Gain?, in which he argued on normative grounds against recognition of the disgorgement interest in contract law. ${ }^{4}$ Furthermore, at the time Restatement Second was published, it was widely assumed by commentators that the disgorgement interest was not protected in contract law. For example, Dobbs's treatise on remedies states:

2. Throughout this Article, I will use the masculine pronoun to refer to the promisee and the feminine pronoun to refer to the promisor.

3. Robert Cooter \& Thomas Ulen, Law \& Economics 234 (3d ed. 2000); see also Robert Cooter \& Bradley J. Freedman, The Fiduciary Relationship: Its Economic Character and Legal Consequences, 66 N.Y.U. L. REv. 1045, 1051 (1991) (in cases involving fiduciary obligations, "perfect disgorgement" is "a sanction that restores the wrongdoer to the same position that she would have been in but for the wrong" and thus "strips the agent of her gain from misappropriation and leaves her no better or worse than if she had done no wrong").

There is a limited exception to the proposition that "if disgorgement is perfect, a promisor is indifferent between doing right, on the one hand, and doing wrong and paying disgorgement damages, on the other hand." If the promisor's gain from breach partly results from her own efforts, and the disgorged gain is not apportioned between the promisor and the promise in a way that reflects those efforts, the promisor would have been better off doing right than doing wrong and paying disgorgement damages. This issue is discussed in Part V.

4. E. Allan Farnsworth, Your Loss or My Gain? The Dilemma of the Disgorgement Principle in Breach of Contract, 94 YALE L.J. 1339 (1985). Farnsworth proposed two or three exceptions to a no-disgorgement rule, but in general these exceptions rested on principles other than recognition of the disgorgement interest-for example, a principle against abuse of contract, and a principle based on the concept that a promise who has a right to specific performance has a property interest in performance.

See also RestatemEnt SeCOND $\$ 370 \mathrm{cmt}$. a ("It is not enough [to provide an entitlement to sue in restitution that the benefit to the promisor] was simply derived from the breach."); id. illus. 4 . 
Writers recognize that there is no general rule allowing restitution of profits [for breach of contract], and plaintiffs seldom seek such restitution .... It is "commonly assumed" that the breacher is not liable for collateral benefits .... The assumptions and practices of the bar, the implications of exceptional cases and the commentary all justify the belief that there is, in practice, a rule against restitution of profits ....s

In contrast, the thesis of this Article is that contract law should and does protect the disgorgement interest. The Article proceeds as follows: In Part I, after showing that the disgorgement interest is widely recognized outside contract law, I address the puzzle why Restatement Second nonetheless rejected that interest. Perhaps the Restatement position was based on the belief that this rejection was compelled by the case law. Alternatively, the Restatement position may have been based on the theory of efficient breach-which was endorsed in a Reporter's Note to the Chapter on Remedies-or other unspoken normative considerations. As I show in Part II, however, rejection of the disgorgement interest is not compelled by the case law; the theory of efficient breach cannot be sustained; and other normative arguments against recognition of the disgorgement interest in contract law are equally unpersuasive. In Part III, I develop categories of cases in which the disgorgement interest in contract law should be protected on the basis of normative considerations, and I discuss a number of cases which have done exactly that. In Part IV, I address the question, if contract law should and does protect the disgorgement interest, why don't we see more disgorgement cases than we do? Finally, in Part V, I consider whether and when a promisor's gain from breach should be apportioned between the promisor and the promisee.

\section{The Disgorgement InTEREst outside Contract LaW}

Damages in private law are usually based on the loss that the plaintiff has suffered as a result of the defendant's wrong. Often, however, a plaintiff's

5. 3 Dan B. DobBs, LaW of Remedies $\S 12.7(4)$, at 171 (2d ed. 1993) (emphasis in original) (citations omitted). Dobbs also stated:

\footnotetext{
Writers sometimes argue for applying the tort rules to contract cases, or to some particular kinds of contract cases. But the practice in contract cases is to the contrary: one who merely breaches a contract is not required to restore collateral profits or gains facilitated by the breach. It is convenient to speak of this strong practice as a rule ... The "rule" merely permits the breacher to retain gains or profits that result from his own breach but that are not the result of the plaintiff's own performance.
}

Id. (footnotes omitted). Note the quotation marks around the word "rule." See also LoN L. FuLLER \& Robert Braucher, Basic Contract Law 55 (1964) ("Perhaps surprisingly, there is no general principle permitting recovery of benefits derived by the defendant as a result of his breach of contract."); 1 George E. Palmer, The LAW of Restitution $\$ 4.9$ (1978) ("Although the issue has gone largely unexplored, it has been commonly assumed that mere breach of contract will not make the defendant accountable for benefits thereby obtained, whether through dealings with a third person or otherwise.") (footnote omitted); John P. Dawson, Restitution or Damages?, 20 OHIO ST. L.J. 175,187 (1959) ("[T]he prevention of profit through mere breach of contract is not yet an approved aim of our legal order ...."); E. Allan Farnsworth, Legal Remedies for Breach of Contract, 70 Colum. L. REv. 1145, 1177 (1970) (quoting Dawson, supra, at 186-87). 
recovery is measured not by his loss, but by the wrongdoer's gain. Cases involving the recovery of a wrongdoer's gain are of two types. In the first type, the plaintiff seeks to recover the value of a benefit the plaintiff conferred upon the wrongdoer. This type of recovery protects the interest that Restatement Second section 344 calls the restitution interest. In the second type, the plaintiff seeks to recover the value of a gain that resulted from or was made possible by the defendant's wrong, but did not consist of a benefit that the plaintiff conferred on the defendant. This type of recovery protects the disgorgement interest. ${ }^{6}$

Disgorgement is an important remedy in various fields of law. For example, it is a central remedy in the law of fiduciary obligations. A fiduciary who wrongfully makes a personal gain through the use of his position, or of property or information that he holds through his position, must disgorge that gain to his beneficiary even if the beneficiary has suffered no loss from the wrong. This principle is exemplified in an illustration to Restatement Third of Agency:

$P$, who owns a stable of horses, employs A to take care of them. While $P$ is absent for a month, and without P's consent, A rents the horses [for his own personal gain] to persons who ride them. Although being ridden is beneficial to the horses, $\mathrm{A}$ is subject to liability to $\mathrm{P}$ for the amount $\mathrm{A}$ receives for the rentals.

A fiduciary is made liable for his gain in such cases partly because a person should not profit from his own wrong, partly because requiring disgorgement gives effect to the beneficiary's implicit expectations, and partly because disgorgement is an instrument of efficiency, since it shapes the conduct of fiduciaries to reflect the reasonable expectations of beneficiaries and provides fiduciaries with correct incentives. ${ }^{8}$

Disgorgement is also commonly awarded where property interests are involved. For example, if Wrongdoer appropriates Owner's property, Wrongdoer is liable in conversion for Owner's loss. Normally, Owner's damages will be measured by the market price of the converted property at the time of conversion. However, if Wrongdoer later sells the property to a third person at a higher price, Owner can require Wrongdoer to disgorge

6. Peter Birks argues that both types of gain-based recovery should be referred to as restitution. Peter H.B. Birks, A Letter to America: The New Restatement of Restitution, 3 GLOBAL JURIST FrontIERS No. 2, Article 2, at 5-10 (2003). Others argue that the term restitution should be reserved for cases in which the plaintiff has conferred a benefit on the defendant, while the term disgorgement should be used where the defendant made a gain that resulted from or was made possible by the wrong, but did not consist of a benefit that was conferred by the plaintiff. See, e.g., James Edelman, Restitutionary Damages and Disgorgement Damages for Breach of Contract, 2000 Restitution L. Rev. 129, 143-44; Lionel D. Smith, The Province of the Law of Restitution, 71 CANADIAN BAR REv. 672, 683-94 (1992). I employ the latter terminology because, especially in contract law, disgorgement cases raise issues not raised by conventional restitution cases.

7. Restatement (Third) of AgenCy $\$ 8.05$, illus. 1 (2006).

8. See Cooter \& Freedman, supra note 3, at 1049-56. 
that price instead of Owner's loss. ${ }^{9}$ If Wrongdoer uses the property, Owner can require wrongdoer to disgorge the rental value of the property, even though that value exceeds the market price of the property. ${ }^{10}$ Similarly, a number of cases have held that if Wrongdoer trespasses on Owner's land, Owner can require Wrongdoer to disgorge the use value of the trespassthat is, the fair rental value of the trespassed property during the relevant period-even though Owner was not harmed. ${ }^{11}$ This result is reflected in an Illustration to a Discussion Draft of Restatement Third of Restitution:

A repeatedly and intentionally trespasses on B's land, avoiding the higher costs of transportation by an alternate route and hoping to avoid paying $B$ for a license. A's saved expenditure (the net costs avoided or the price of a license, whichever is higher) is an unjustified enrichment because it is the result of a legal wrong ....A is liable to $B$ in restitution in the amount of A's saved expenditure, whether or not A's repeated trespass has caused any injury to $B$ 's land. ${ }^{12}$

\section{The Puzzle of Restatement Second}

Given the well-accepted protection of the disgorgement interest in other areas of law, what explains Restatement Second's position that contract law does not protect the disgorgement interest? There are two possibilities. The drafters of Restatement Second may have held either the view that the exclusion of the disgorgement interest from section 344 was dictated by positive law or the view that the exclusion was normatively justified. At least today, neither view can be supported.

9. Historically, this remedy was known as waiving the tort and suing in assumpsit, on the fiction that Owner can elect to treat Wrongdoer as an agent who made the sale of the converted property on Owner's behalf. See 1 DoBBs, supra note $5, \S 4.2(3)$.

10. See, e.g., Olwell v. Nye \& Nissen Co., 173 P.2d 652 (Wash. 1946).

11. See, e.g., Quality Excelsior Coal Co. v. Reeves, 177 S.W.2d 728, 732 (Ark. 1944) (" $[W]$ hen the defendant has beneficially occupied the property, he may be held liable in an action of trespass for its fair rental value, even though the plaintiff was not hindered or obstructed in any use which he expected to make of the property.") (internal quotation marks omitted); Bourdieu v. Seaboard Standard Oil Corp., 119 P.2d 973 (Cal. Dist. Ct. App. 1941) (“'[R]easonable rental value affords a proper measure of damages in a case of trespass." ") (quoting Lindberg v. Linder, 23 P.2d 842, 844 (Cal. Dist. Ct. App. 1933)); Slovek v. Bd. of County Comm'rs, 697 P.2d 781 (Colo. Ct. App. 1984); Anchorage Yacht Haven, Inc. v. Robertson, 264 So. 2d 57, 61 (Fla. Dist. Ct. App. 1972) (action for trespass when defendant's boat sank in plaintiff's basin; the court held that damages could include the reasonable rental value of the space occupied by the boat); Balt. \& Ohio R.R. Co. v. Boyd, 10 A. 315, 317-18 (Md. 1887) (Railroad had for a number of years trespassed on the plaintiff's land and court said it was "true, there is no evidence whatever of any special damages sustained, or that the plaintiffs were hindered or obstructed in any proposed used of their lot, by reason of the presence and use of the railroad tracks; but, nevertheless, we are of opinion that the plaintiffs are entitled to a reasonable compensation for the use of their land, and we think this is measured by what would be a fair rental value for the ground.").

12. Restatement (ThiRd) of Restitution and UnJust EnRIChment $§ 1$, illus. 5 (Discussion Draft No. 1, 2001). 


\section{A. Positive-Law Considerations}

The first possible explanation turns on positive-law considerations. As Dobbs's treatise shows, until recently it was commonly assumed by commentators that contract law does not protect the disgorgement interest. However, there is only limited support for that assumption in the case law, especially at the appellate level. Farnsworth cites no cases that directly support the proposition. Dobbs cites only one case, and instead relies primarily on "writings," "assumptions," and the "practices of the bar." cites-Burger King Corp. v. Madison ${ }^{14}$-is of doubtful authority. Burger King was a diversity case which purported to apply Florida law. In reality, however, the Florida Supreme Court, in cases decided both before ${ }^{15}$ and after ${ }^{16}$ Burger King, has given strong protection to the disgorgement interest in contract law. Restatement Second's position seems to be supported by only a few other appellate cases, principally United States Naval Institute Press $v$. Charter Communications, Inc., ${ }^{17}$ and a smattering of lower-court cases. ${ }^{18}$ In contrast, more than a dozen appellate cases decided by various state

13. See 3 Doввs, supra note 5.

14. 710 F.2d 1480 (11 th Cir. 1983).

15. Gassner v. Lockett, 101 So. $2 \mathrm{~d} 33$ (Fla. 1958) (requiring disgorgement of profits made as a result of the breach of a contract to sell a home, followed by a sale to a third party at a higher price).

16. Coppola Enterprises v. Alfone, 531 So. 2d 334 (Fla. 1988) (same). This case is discussed infra notes 62-63 and accompanying text.

17. 936 F.2d 692 (2d Cir. 1991); see also Bachewicz v. Am. Nat'l Bank \& Trust Co., 466 N.E.2d 1096 (Ill. App. Ct. 1984). In Axford v. Price, 61 S.E.2d 637, 642 (W. Va. 1993), the West Virginia Supreme Court held that the "measure of damages recoverable for the breach of a covenant of the seller of a business not to reengage in the business in competition with the purchaser is the value of the business lost by plaintiff and not the gain of defendant resulting from his breach of the covenant." This relatively specific holding is out of step with the great majority of cases on the measurement of damages in this context. See infra text accompanying notes 73-76, and cases cited in notes 73-75. In Abex Corp./Jetway Div. v. Controlled Systems, Inc., No. 92-1368, 1993 U.S. App. LEXIS 321 (4th Cir. Jan. 12, 1993), a diversity case involving a similar context and decided under West Virginia law, the court, relying on Axford, held that disgorgement was an inappropriate remedy under West Virginia law. The court also cited Burger King, and based its conclusion in part on the incorrect premise that "awarding more than expectation damages prevents an efficient breach." Abex, 1993 U.S. App. LEXIS at *31 n.11. The opinion in Abex was not published. Under the Fourth Circuit's Local Rule 36(c), in the absence of unusual circumstances the court will not cite an unpublished opinion, and citation of unpublished opinions to the court is disfavored. In Kerin v. United States Postal Service, 116 F.3d 988 (2d Cir. 1997), a landlord had leased a building to the Postal Service. The lease limited occupancy to thirty employees. The Postal Service had more than thirty employees in the building, which resulted in damages to the septic system and the parking area. The landlord sued for breach of the lease provisions and for unjust enrichment based on the benefit to the Postal Service of having more than thirty employees in the building. The court granted the damages claim but, applying Connecticut law, denied the unjust enrichment claim on the grounds the damages claim was comprehensive and the unjust enrichment claim was duplicative, and that a plaintiff suing in unjust enrichment must show that the enrichment caused the plaintiff harm. The last point may be Connecticut law, but the law of unjust enrichment normally does not require a showing that the plaintiff was harmed. See also cases cited infra note 89.

18. See, e.g., Topps Co. v. Cadbury Stani S.A.I.C., 380 F. Supp. 2d 250 (S.D.N.Y. 2005) (citing Burger King); Curley v. Allstate Ins. Co., 289 F. Supp. 2d 614 (E.D. Pa. 2003) (citing Dobbs and Farnsworth); Dethmers Mfg. Co. v. Automatic Equipment Mfg. Co., 73 F. Supp.2d 997 (N.D. Iowa 1999); Glendale Federal Bank, ESB v. United States, 43 Fed. Cl. 390 (1999). 
appellate courts, the United States Supreme Court, the House of Lords, and the highest courts of other common law jurisdictions have awarded disgorgement in a contract setting. (Many of these cases, along with Naval Institute, will be discussed in Part III.)

Nor is there a convincing normative argument in favor of Restatement Second's position. In the balance of this Part, I will explicate several such arguments, based on causation and efficiency. I will show that all these arguments fail.

\section{B. The Causation Arguments}

Three causation arguments against protection of the disgorgement interest in contract law are at the center of Farnsworth's leading article, Your Loss or My Gain? Farnsworth calls these arguments "cause in fact," "remote cause," and "joint cause."19 These causation arguments are flawed in various ways. Among other things, none are really arguments against protection of the disgorgement interest in contract law. Instead, as I will show, the arguments only concern how disgorgement damages should be measured.

1. Cause in fact: saving the cost of obtaining a release from the promisee. First, Farnsworth claims that if a breach makes possible a gain that the promisor would not have realized through performance, the breach is not the cause in fact of the entire gain. The promisor, Farnsworth argues, could have arranged to realize the gain through some means other than breach-in particular, by negotiating a release from the promisee. In that case, Farnsworth argues, the gain made possible by the promisor's breach is only the amount that the promisor would have had to pay the promisee for the release.$^{20}$ So, for example, if a breach makes it possible for the promisor to gain $\$ 10,000$ more than she would have gained from performance, but the promisee would have released the promisor from the contract for $\$ 4,000$, Farnsworth argues that the gain caused by the breach is only $\$ 4,000$, the amount the promisor gained by not obtaining the release. ${ }^{21}$

This reasoning is highly unpersuasive. To begin with, under any normal conception of "cause" the promisor's breach would be a cause-both a butfor and a proximate cause - of her $\$ 10,000$ gain from breach. After all, the promisor is able to make the $\$ 10,000$ gain from breach only because she breaches.

Putting that aside, Farnsworth's cause-in-fact argument is not really an argument against protecting the disgorgement interest in contract law. On the contrary, the argument implicitly recognizes that interest. If a promisee sued for breach, the amount that the promisor would have had to pay to obtain a release would not be an element of either expectation, reliance, or restitution damages, and could be recovered only if the disgorgement

19. Farnsworth, supra note 4.

20. Id. at 1346.

21. Id. at $1346-47$. 
interest was protected. Accordingly, the cause-in-fact argument concerns only how much the promisor should disgorge, not whether the promisor should disgorge.

Next, there is no natural stopping point to the reasoning that the only loss caused by a breach is the amount the injured party would have required to forgo his rights. If there is a causation problem in contract law of the kind that Farnsworth's cause-in-fact reasoning depends upon, the same causation problem would affect other areas of law as well. For example, suppose an agent improperly uses her principal's property in a way that does not harm the principal. Under Farnsworth's reasoning, the principal, $P$, should be able to recover only the amount that he would have required the agent to pay for P's consent to the use, because that would be the only loss the agent caused in fact. The same would be true of a trustee who improperly uses trust property without harming the beneficiary, or a corporate director who improperly uses corporate property without harming the corporation. ${ }^{22}$

Moreover, the brute reality is that Farnsworth's cause-in-fact argument depends on a counterfactual premise. Even if the promisor could have obtained a release from the promise, she did not do so. If a promisor wants to not perform, her proper course of action is to renegotiate the contract to obtain a release or a modification. Farnsworth's cause-in-fact argument, however, treats a breaching promisor who wrongly fails to renegotiate just as well as a promisor who does properly renegotiate, and as a result does not breach. To measure the promisee's damages as if the promisor had renegotiated, when in fact she did not, is to reward the promisor for doing the wrong thing and to remove from the promisor an incentive to do the right thing. This problem is well brought out in a comment on Farnsworth's article by one of my former students, which I here paraphrase:

The logical structure of Farnsworth's argument is as follows: Instead of not breaching her contract, the promisor sold to a third party (the "overbidder"). But the promisor could have negotiated with the promisee for a release, which would have allowed her both to not breach and to sell the commodity to the overbidder. So instead of disgorging the profit from selling to the overbidder, the promisor should pay for not having negotiated with the promisee for a release, because what really prevented the promisor from not breaching was not having obtained a release.

22. Conversely, while Farnsworth's cause-in-fact reasoning would improperly decrease damages in some cases, it would improperly increase damages in others. For example, there are a number of cases, which will be considered later in this Article, in which a contracting party fails to provide promised services, and it is clear that the promisee's cost for completion-the cost or replacing those services-is well in excess of the value of the services to him. Accordingly, if the promisee is awarded damages measured by cost of completion, rather than by diminished-value damages (the difference between the value of his property as it is, and the value it would have if the services were rendered), he would not use the damage award to complete the unrendered performance. In such cases, the rule should be and is that the promisee's recovery is limited to diminishedvalue damages, or, in certain cases, to the costs saved by the promisor, where the promisee has effectively paid the promisor to incur those costs. Under Farnsworth's cause-in-fact reasoning, however, the promisee should be entitled to the amount he would have been able to extract from the promisor in exchange for a release from the contract, which would be well in excess of the promisee's real loss. 
But who cares what the promisor could have done? The availability of negotiating for the release makes the promisor even more culpable. She had the opportunity to negotiate for the release, which would have allowed her both to not breach and to sell to the overbidder. But instead she chose to not negotiate for the release, and to breach. If we think that not breaching contracts is important, we need to give incentives for doing all of not breaching, negotiating for a release, and, if the release is obtained, selling to the overbidder. Disgorgement would do this, because it takes away the incentives to just breach. ${ }^{23}$

Finally, a measure of recovery based on the cost of obtaining a release would be virtually unadministrable, because the amount that a promisee would have required to give a release is not only unknown but in most cases unknowable.

2. Joint cause; apportionment. Next, Farnsworth argues that recognition of the disgorgement interest would raise a problem that he calls joint cause, a term he uses to describe cases in which the promisor's gain from breach resulted in part from the promisor's own skill and diligence. ${ }^{24}$ For example, suppose Seller contracts to sell to Buyer the Acme Hotel in Chicago for $\$ 60$ million, with closing in one month. After making the contract, Seller continues to seek out other buyers for the Acme, and locates Overbidder. Overbidder has a strategic need for the Acme, because he is putting together a hotel chain and needs a hotel in Chicago to complete the chain. Because of this need, Overbidder is willing to pay $\$ 65$ million for the Acme, which is more than anyone else would pay. Seller sells the Acme to Overbidder for that price.

Assume that the market value of the Acme Hotel, based on extrapolation from the sales of comparable hotels, is $\$ 61$ million. If specific performance is unavailable (because, for example, Seller completes the sale of the Acme to Overbidder before Buyer can get to court), Buyer's expectation damages would be $\$ 1$ million, leaving Seller with a gain of $\$ 4$ million from the breach. Some part of this $\$ 4$ million gain, however, resulted from Seller's skill and diligence in locating Overbidder. How, Farnsworth asks, is a court to respond, in such a case, to the promisor's argument that some apportionment from the gain from breach is required ? $^{25}$

As in the case of the cause-in-fact argument, "joint cause" is not an argument against protecting the disgorgement interest in contract law. Instead, it is only an argument about how to measure disgorgement damages, because unless disgorgement is awarded, there is nothing to apportion.

Furthermore, apportionment will seldom be a real issue in contract disgorgement cases. To begin with, in many or most cases the gain made possible by a promisor's breach will not be a result of the promisor's skill and diligence. For example, in a variant of the Acme Hotel hypothetical,

23. E-mail from Howard Tony Loo to author (Apr. 24, 2002) (on file with Michigan Law Review).

24. Farnsworth, supra note 4, at 1347.

25. Id. 
Overbidder may offer to buy the Acme from Seller without Seller having solicited the offer, because Overbidder independently identified the Acme as a desirable purchase. In such cases, Seller's skill and diligence will not have contributed to her gain.

Even where part of the promisor's gain from breach does result from her skill and diligence, often it will be improper to give her credit for that part of the gain. If an agent wrongly uses his principal's property to make a gain (as in the stable-horse illustration in Restatement Third of Agency), an apportionment of part of the gain to the agent, on the ground that the agent's skill and diligence contributed to the gain, would be improper, because it would reward the agent for committing a wrong and would subvert the agent's duty of loyalty. Similarly, as I will show in Section III.B, in a case like Acme Hotel, even if Seller finds Overbidder through the exercise of skill and diligence, Seller's gain from breach should not be apportioned between Seller and Buyer, because Seller wrongfully breached the contract by searching for an overbidder after she had contracted to sell to Buyer.

There are cases in which an apportionment of the gain from breach is appropriate. I will discuss the principles that should govern such cases in Part V. At this point, suffice to say that the possibility that in some cases the promisor's gain from breach should be apportioned between the promisor and the promisee is not a reason against protection of the disgorgement interest in contract law, any more than the doctrine of comparative negligence is an argument against the principle of negligence in tort law.

3. Remote cause; tracing. Finally, Farnsworth raises the question, if a breaching promisor uses her gain from breach to make an investment, and earns a profit on the investment, should the promisee recover not only the gain from breach, but also the proceeds of the investment? ${ }^{26}$

As in the case of Farnsworth's cause-in-fact and joint-cause arguments, the problem that Farnsworth calls "remote cause" is not an argument against disgorgement, but only a problem of how disgorgement damages should be measured. Furthermore, the answer to Farnsworth's question is simple. In cases involving the disgorgement, it would almost invariably be inappropriate to allow the promisor to recover the proceeds of an investment made with the gain. Most gains of this type would be cut off by the foreseeability doctrine of Hadley v. Baxendale. ${ }^{27}$ More important, normally there would be neither a good purpose nor a need for such a recovery. Unless the breach freed up cash for the promisor, and the promisor had no free cash other than her gain from breach, the breach would not make her investment possible, because she could have made the investment even if she did not breach. The issue that Farnsworth calls "remote cause" therefore presents no more reason against protection of the disgorgement interest in contract law than do the issues he calls "cause in fact" and "joint cause."

26. Id. at 1349 .

27. 156 Eng. Rep. 145 (Ex. 1854). 
In short, arguments based on causation fail to show that contract law should not protect the disgorgement interest. ${ }^{28}$

\section{The Theory of Efficient Breach}

So far, I have shown that positive law does not present a barrier to protection of the disgorgement interest in contract law, and neither does the problem of causation. There are, however, two arguments based on efficiency that might seem to present such a barrier. The first argument is based on the theory of efficient breach. This theory holds that breach of contract is efficient, and therefore desirable, if the promisor's gain from breach, after payment of expectation damages, will exceed the promisee's loss from breach. Richard Posner gives probably the best-known exposition of the theory of efficient breach in his book Economic Analysis of Law. ${ }^{29}$ This exposition has changed somewhat over the six editions of that book. Here is the core of the exposition in the first edition:

[T]n some cases a party [to a contract] would be tempted to breach the contract simply because his profit from breach would exceed his expected profit from completion of the contract. If his profit from breach would also exceed the expected profit to the other party from completion of the contract, and if damages are limited to loss of expected profit, there will be an incentive to commit a breach. There should be.:0

If this theory were correct, it would be an argument against protecting the disgorgement interest in contract law: if the promisor is required to disgorge her gain from breach, she will have no incentive to breach where her gain from breach exceeds the promisee's loss. ${ }^{31}$ However, the theory is incorrect, and indeed if widely adopted it would lead to inefficiency. I have

28. Farnsworth calls for recognizing certain exceptions to the no-disgorgement rule he proposes. One exception involves cases in which the promisee was entitled to specific performance of a contract to convey property; another involves what Farnsworth calls "abuse of contract." See id. at $1368,1382-91$, and infra note 31 . It is not entirely clear how Farnsworth reconciled his causation arguments with these exceptions.

29. See Richard A. Posner, Economic Analysis of LaW 57 (1972).

30. Id. (emphasis added). Note that Posner states here that "if damages are limited to loss of expected profit" there will be an incentive to commit breach when the promisor's gain from breach will exceed the promisee's loss. Clearly, however, Posner's conclusion is that if the promisor's gain from breach will exceed the promisee's loss, the remedy for breach of contract should be limited to the promisee's loss.

31. Indeed, because the theory of efficient breach assumes the desirability of expectation damages, essentially the only operational consequences of the theory, if it were correct, would be that contract law should rarely if at all award specific performance, punitive damages, or disgorgement. For arguments against protection of the disgorgement interest in contract law based on the theory of efficient breach, see Sidney W. DeLong, The Efficiency of a Disgorgement as a Remedy for Breach of Contract, 22 IND. L. REv. 737, 742-45, 775 (1989); Farnsworth, supra note 4, at 1380-82. Like Farnsworth, DeLong recognizes a few kinds of cases in which disgorgement should be granted. See, e.g., DeLong, supra, at 760-68 (noting an exception for disgorgement of prejudgment interest). 
discussed this theory at length elsewhere ${ }^{32}$ and therefore will treat it here in a relatively summary fashion.

Although the theory of efficient breach is stated in general terms, in fact it can only be evaluated in the context of specific paradigm cases. I will call the most significant of these paradigms-indeed the poster-child of the theory-the Overbidder Paradigm. In this Paradigm, a seller who has contracted to sell a commodity to a buyer breaches the contract in order to resell the commodity to a third party-the overbidder-who comes along later and offers a higher price. ${ }^{33}$ For example, here is the centerpiece illustration of the theory in the first edition of Posner's Economic Analysis of Law:

I sign a contract to deliver 100,000 custom-ground widgets at $\$ .10$ apiece to A, for use in his boiler factory. After I have delivered 10,000, B comes to me, explains that he desperately needs 25,000 custom-ground widgets at once since otherwise he will be forced to close his pianola factory at great cost, and offers me $\$ .15$ apiece for 25,000 widgets. I sell him the widgets and as a result do not complete timely delivery to $A$, who sustains $\$ 1000$ in damages from my breach. Having obtained an additional profit of $\$ 1250$ on the sale to B, I am better off even after reimbursing A for his loss. Society is also better off. Since B was willing to pay me $\$ .15$ per widget, it must mean that each widget was worth at least $\$ .15$ to him. But it was worth only $\$ .14$ to $\mathrm{A}-\$ .10$, what he paid, plus $\$ .04$ ( $\$ 1000$ divided by 25,000 ), his expected profit. Thus the breach resulted in a transfer of the 25,000 widgets from a lower valued to a higher valued use. ${ }^{34}$

In the context of the Overbidder Paradigm, the theory of inefficient breach is incorrect for three reasons: (1) it rests upon incorrect factual predicates; (2) it does not have any support in efficiency; and (3) if widely followed, it would lead to inefficiency.

1. The incorrect factual predicates. In the context of the Overbidder Paradigm, the theory of efficient breach rests on two basic factual predicates, both of which feature in Posner's illustration, and both of which are incorrect.

The first predicate is that the expectation measure makes the promisee subjectively indifferent between performance and damages. This predicate is incorrect because expectation damages do not have that effect. Among other things: expectation damages are based on objective rather than subjective value; the profits a buyer would have earned if performance had occurred are often cut off by the principle of Hadley v. Baxendale, ${ }^{35}$ by the certainty rule, or by both; expectation damages do not include legal fees and other costs of dispute-settlement and litigation, which would not have been incurred if the promisor had performed; and prejudgment interest for breach

32. See Melvin A. Eisenberg, Actual and Virtual Specific Performance, the Theory of Efficient Breach, and the Indifference Principle in Contract Law, 93 CAL. L. Rev. 975 (2005).

33. By "commodity," I mean anything that can be purchased or sold, including goods, services, and real estate.

34. POSNER, supra note 29, at 57.

35. 156 Eng. Rep. 145 (Ex. 1854). 
of contract is often not awarded, and when awarded is almost invariably less than the time value of the gains that the promisee would have made from performance. $^{36}$

The second predicate of the theory of efficient breach is that at the time of the perform-or-breach decision, the promisor knows the value that the promisee places on a contracted-for commodity. This predicate is incorrect, in that context, because the seller will seldom have such knowledge. In the context of the Overbidder Paradigm, if the theory of efficient breach had any validity at all, it would normally be limited to contracts for differentiated commodities. ${ }^{37}$ In the case of such contracts, however, at the time of contract-formation a buyer will rarely if ever tell a seller what profit he expects to make from a contract, because a seller could use that information to lever up the price. Even if the buyer did disclose that information, the seller would normally have no way of knowing what profits the buyer expected to make at the time of the seller's perform-or-breach decision, because between the time of contract-formation and the time of that decision, markets may have shifted, or the buyer may have increased his potential profits through an investment in beneficial reliance-such as advertising or the purchase of complimentary commodities-which will be wasted if the seller breaches.

This informational flaw in the theory of efficient breach is thrown into sharp relief by a competing theory, which I will call the theory of efficient termination. As formulated by Paul Mahoney, this theory simply holds that it is often more efficient to terminate a contract than to perform it:

\begin{abstract}
Efficient termination is possible when the amount of money, $Y$, that [the promisor] would pay to escape performance at a particular point in time is greater than the amount of money, $Z$, that the promisee ... would accept in lieu of performance. In that situation there is a potential gain of $Y-Z$ from terminating the contract. ${ }^{38}$
\end{abstract}

The difference between the two theories is as follows. At the risk of oversimplification, a contract can be terminated in two very different ways: mutually, by rescission, or unilaterally, by breach. The theory of efficient breach contemplates only unilateral termination by breach, and in the context of the Overbidder Paradigm, the theory incorrectly assumes that a breaching seller will have full information about the value the buyer places on the contracted-for commodity at the time of breach. In contrast, the theory of efficient termination contemplates termination by mutual consent, because it is only through mutual consent that the parties can establish an amount that the promisee will accept in lieu of performance. The theory of efficient termination also has a moral dimension, because it requires the

36. See Eisenberg, supra note 32, at $989-96$.

37. See id. at 999.

38. Paul G. Mahoney, Contract Remedies and Option Pricing, 24 J. LEG. STuD. 139, 141 (1995). 
promisor to accord to the promisee the respect that a promisee is due in that capacity, by seeking to obtain the promisee's consent to nonperformance.

In short, as compared with the theory of efficient breach, the theory of efficient termination contemplates that termination of a contract will occur through a process that involves a much richer mix of information; allows the promisee to insist on being paid his actual value for the contracted-for commodity; and helps ensure that promisees are treated with due respect.

2. The lack of an efficiency basis for the theory. Even assuming, counterfactually, that the predicates of the theory of efficient breach are correct, in the context of the Overbidder Paradigm the encouragement of breach would not promote efficiency. The efficiency justification of that theory in this context is that if a seller's gain on a sale to an overbidder exceeds the buyer's loss, breach is an instrument for transferring a commodity to a higher-valued use. ${ }^{39}$ However, in a world without transaction costs, commodities will always flow to higher-valued use. In such a world, therefore, if the overbidder values the commodity more than the buyer, he will end up with the commodity even if the theory of efficient breach is rejected. Commodities will also normally flow to higher-valued uses in a world with transaction costs. If the overbidder values the commodity more than the buyer, and knows the buyer's identity, he will purchase, from the buyer, either an assignment of the contract or the commodity itself. If the third party does not know the buyer's identity, a rational seller will either negotiate with the buyer to be released from the contract so that she can sell to the overbidder, or will sell the overbidder's identity to the buyer or the buyer's identity to the overbidder. ${ }^{40}$

3. The inefficiency of the theory. In short, in the context of the Overbidder Paradigm there is no convincing efficiency justification for the theory of efficient breach. But there is more. If the theory were widely followed, it would lead to inefficiency. There are several reasons why this is so. For example, the theory would give the wrong incentives for planning, by allocating commodities to an overbidder who lacked the foresight or the willingness to invest in ensuring his supply of the relevant commodity by making a forward contract, and away from a buyer who did have the foresight and did make the investment in such a contract.

In addition, the theory would diminish the efficiency of the contracting system. The efficiency of that system does not rest, as the theory of efficient breach implies, solely on legal remedies. Rather, the efficiency of the system resis on a tripod whose legs are legal remedies, reputational effects, and the internalization of social norms-in particular, the

39. See PosNer, supra note 29.

40. Posner more or less admitted that if an overbidder values the contracted-for commodity more than the buyer, the overbidder will end up with the commodity even if the seller is not allowed to breach. He then fell back on an argument that the transaction costs of moving a commodity to an overbidder will be less in an efficient-breach regime than in a performance regime. Id. In fact, however, it is impossible to show that the transaction costs of moving commodities to higher-valued uses would be less under an efficient-breach regime than under a performance regime, and given the costs of dispute settlement and litigation and of searching for and negotiating with the overbidder, the transaction costs of such movements would almost certainly be greater in an efficient-breach regime than in a performance regime. 
moral norm of promise-keeping. These three legs are mutually supportive. Because all three legs are necessary to support the efficiency of the contracting system, anything that weakens one leg seriously threatens the efficiency of the system. The theory of efficient breach, if widely adopted, would do precisely that because the effect of the theory would be to remove the moral force of promising in a bargain context. The moral meaning of making a promise is to commit yourself to take a given action in the future, even if, when the action is due to be taken, all things considered you no longer wish to take it. The theory of efficient breach turns this upside down. Under that theory, if you don't wish to take a promised action when it is due, because all things considered you believe that if you take the action your forgone gain would exceed the gain to the promisee, you shouldn't keep the promise. ${ }^{41} \mathrm{By}$ removing the moral leg of the system, the theory would inefficiently increase the need to resort to litigation, which is very expensive, as opposed to achieving performance of contracts through the internalization of the moral norm of promise-keeping, which is very inexpensive.

Most important for present purposes, in the context of the Overbidder Paradigm the theory of efficient breach would inefficiently remake the parties' contract. It is a fundamental premise of contract law that autonomous and well-informed actors are the best judges of their own utility, so that enforcing bargain contracts is efficient, in the absence of defenses such as fraud, duress, unconscionability, or the like. Contracts consist of both explicit and implicit or implied terms, and it is equally efficient to enforce either kind of term. A basic algorithm for determining the implicit or implied terms of a contract is to ask what terms actors situated like the parties to the contract would likely either have agreed upon or tacitly assumed.

Let us apply this algorithm to the theory of efficient breach in the context of the Overbidder Paradigm. Suppose a seller and a buyer have negotiated a contract under which the seller agrees to sell a differentiated commodity to the buyer - for example, a home to live in or a used die press that the buyer will employ as a factor of production. As the parties are about to sign a written contract, the seller says, "In all honesty, I should tell you that although I have no present intention to breach this contract, neither do I have a present intention to perform. If a better offer comes along, I will take it and pay you expectation damages. In fact, I will begin actively looking for a better offer right after we sign this contract. Let's insert a provision that recognizes that I will do just that."

Experience strongly suggests that in real life most buyers would be surprised if not shocked by such a statement, and would either walk away; insist on an explicit contractual provision stating that the seller has a present intent to perform and that any profit on breach and resale will go to buyer; or demand a payment, in the form of a lower price, for the seller's right to resell. Buyers will react this way because, as Ian Ayres and Gregory Klass

41. Recall Posner's conclusion that if the seller's gain from breach will exceed the buyer's loss, then "if damages are limited to loss of expected profit, there will be an incentive to commit a breach. There should be." Id. (emphasis added). 
conclude, normally one point of a bargain promise is to convince the promisee that the promisor has an intent to perform:

[T] here are good reasons why promisors want to implicitly say that they intend to perform ... rather than that they intend to perform or pay damages, or that they do not intend not to perform, or [to implicitly say] nothing at all about their intent. Promisees care about promisor intent because they care deeply about whether or not the promisor will perform. If a promisee thinks that the promisor does not intend to perform and is seriously considering the option of paying damages instead, then he is much less likely to rely on her promise, be it by entering into a binding contract or by otherwise ordering his behavior as if performance were going to happen. But the whole point of promising is to convince others to rely on one's future actions. Thus promisors have a natural incentive to communicate with their promisees an intent to perform. This fact explains why most promises represent an intent to perform and why the law should adopt a default interpretation that recognizes this fact. ${ }^{42}$

One reason why this is so is that expectation damages are far from sufficient to make a promisee indifferent between performance and damages. But there is a much stronger reason. When buyers contract for the purchase of a differentiated commodity they are usually motivated not simplysometimes not at all-by a desire to shift the risk of increased prices. Instead, they are usually motivated in significant part, sometimes even entirely, by a desire to coordinate and stabilize their planning and production by locking in the supply of inputs and factors of production and distribution. This lock-in allows buyers to confidently engage in long-term production projects and to make expenditures on contract-specific and wealth-increasing reliance, such as advertising or the acquisition of control over complementary inputs and factors. Indeed, even where a shift in price risk is an important purpose of a contract, the buyer's desire to acquire control over inputs and factors of production and distribution is often equally or more critical. An example is a contract for just-in-time delivery of components for manufactured goods, where delays in delivery would ordinarily be much more costly to the buyer than price increases. Lisa Bernstein reports some examples of this kind of phenomenon in the cotton trade:

When asked why breach, even with payment of market-difference damages, upsets someone, [a cotton executive] explained that "most of the contracts in the cash market involve a merchant buyer who has or will contract with an end-user, or are transactions directly to end-users. These endusers need to get trucks and rail cars and scheduling unloading at particular times, all of which is very complex., ${ }^{, 43}$

$* * *$

42. Ian Ayres \& Gregory Klass, Promissory Fraud Without Breach, 2004 Wis. L. Rev. 507, 513-14.

43. Lisa Bernstein, Private Commercial Law in the Cotton Industry: Creating Cooperation through Rules, Norms, and Institutions, 99 Mich. L. REv. 1724, 1755 n.135 (2001). 
As one industry participant noted, "any departure from the 'my word is my bond' method of doing business [is] viewed as introducing uncertainty into the contract process, something that is viewed as per se undesirable .... [T] he desire to run a smooth business is key to mills and people prefer to deal with reliable folks . ..."44

Furthermore, even if, counterfactually, expectation damages made a promisee indifferent between performance and damages if damages are awarded, because of the vagaries of litigation a promisee cannot be sure whether damages will be awarded. Buyers do not contract for the expensive, emotionally draining, hassling game of chance that litigation constitutes. Instead, buyers contract for goods and services to be delivered when they are supposed to be delivered.

The point that a contract for sale implicitly prohibits a seller from searching for an overbidder or accepting an overbid is forcefully made in Greer Properties, Inc. v. LaSalle National Bank, ${ }^{46}$ a Seventh Circuit opinion which Judge Posner joined. Sellers contracted to sell a parcel of real estate to Greer for $\$ 1,250,000$. Sellers were required to clean up environmental contamination of the property at their own expense, but were allowed to terminate the contract if the cost of the clean-up became impracticable. Thereafter, Sellers reopened negotiations with Searle Chemicals, which had previously been interested in the parcel; agreed to sell the parcel to Searle for $\$ 1,455,000$; and terminated the contract with Greer, purportedly under the clean-up provision. The Seventh Circuit held that by making the contract with Greer, Sellers had given up their right to look for a better price:

Under Illinois law, "every contract implies good faith and fair dealing between the parties to it." This implied obligation of good faith and fair dealing in the performance of contracts acts as a limit on the discretion possessed by the parties....

With this limitation on the discretion of the Sellers in mind, their decision to terminate the contract must be analyzed to determine if they acted in good faith. If the Sellers terminated the contract to obtain a better price from Searle, their action would have been in bad faith. When the Sellers entered the contract with Greer and Greer agreed to pay them a specific price for the property, the Sellers gave up their opportunity to shop around

\section{Id. at $1755-56$.}

45. Survey evidence also supports the conclusion that a contracting promisee normally expects that the promisor is committed to performance. In 1990, David Baumer and Patricia Marschall surveyed 119 North Carolina corporations about their attitudes towards willful breach. David Baumer \& Patricia Marschall, Willful Breach of Contract for the Sale of Goods: Can the Bane of Business be an Economic Bonanza?, 65 TEMP. L. Rev. 159 (1992). One question was "If a trading partner deliberately breaches a contract because a better deal can be had elsewhere, is such behavior unethical?" One hundred and five respondents said yes. In addition, eighty-six said that they would always or almost always withhold future business from a party who had willfully breached. Id. at 165-66. These responses can be explained only if promisees understand a contract of sale as a commitment by the promisor to performance, not as a commitment to perform or pay damages at the promisor's option.

46. 874 F.2d 457 (7th Cir. 1989). 
for a better price. By using the termination clause to recapture that opportunity, the Sellers would have acted in bad faith. ${ }^{47}$

\section{The Efficiency of Expectation Damages}

In short, the theory of efficient breach does not provide a normative reason for the rejection of the disgorgement interest in Restatement Second, because at least in the context of the Overbidder Paradigm, the theory has no validity. Accordingly, I turn now to another possible efficiency-based argument that might be advanced against protection of the disgorgement interest. This argument would proceed as follows: Perfect expectation damages promote efficiency, because the prospect of such damages leads a promisor to internalize the promisee's potential gains under the contract, and therefore gives the promisor appropriate incentives in making performor-breach decisions and in deciding how much precaution to take to ensure that she will be able to perform when the time comes. Generally speaking, however, a promisee will seek disgorgement damages only when they exceed expectation damages. Therefore, protection of the disgorgement interest would provide the promisor with excessive incentives for performance and precaution.

There are several problems with such an argument. First, an argument based on the efficiency effects of perfect expectation damages is not compelling. The expectation measure would be perfect only if it made the promisee indifferent between performance and breach; under present law this will never occur. ${ }^{48}$

Second, even if the expectation measure is the gold standard in contract law, where expectation damages are difficult to measure, the best way to ensure protection of the expectation interest may be to use disgorgement as a surrogate for expectation damages, just as reliance is sometimes used as a surrogate for expectation. ${ }^{49}$ For example, where $A$ gives $B$ a noncompete agreement and then proceeds to compete, if $B$ 's losses from the competition are difficult to measure directly, $A$ 's profits can be used as an indirect measure of the losses. ${ }^{50}$

Third, and most important, the expectation measure is not an end in itself. Rather, the expectation measure is normally the best way to provide efficient incentives for precaution and performance and to effectuate bargain contracts—or at least it would be if expectation damages were perfect. As I will show in Part III, however, in certain categories of cases protection of the disgorgement interest is the best or only way to provide efficient incentives and to effectuate bargain contracts. Furthermore, frequently disgorgement

\footnotetext{
47. Id. at 460-61 (emphasis added)(citations omitted).

48. See supra text accompanying note 35 .

49. See Sec. Stove \& Mfg. Co. v. Am. Ry. Express Co., 51 S.W.2d 572 (1932).

50. See infra note 73 .
} 
damages are expectation damages, because the promisee has bargained for disgorgement of the promisor's gains from breach. ${ }^{51}$

\section{Why Contract LaW Should and Does}

\section{Protect THE Disgorgement INTEREST}

In Parts I and II, I showed that the position taken in Restatement Second against recognition of the disgorgement interest in contract law lacks strong support in the case law, and that the normative arguments that have been or might be made in favor of that position fail. In this Part, I will discuss the affirmative reasons why the disgorgement interest should be protected where appropriate. I will begin with the general reasons for protecting that interest, and then consider various categories of cases that implicate those reasons. In the course of the discussion, I will consider a number of decisions that have protected the disgorgement interest in these categories.

\section{A. The General Argument}

Although the assumption that contract law does not protect the disgorgement interest has been widely accepted, since the 1950s there have been periodic expressions of support for disgorgement in the secondary literature. Some of this support was relatively conclusory and seems to have been based in large part on moral intuitions concerning the validity of allowing a

51. Hanoch Dagan has made still another efficiency argument against protection of the disgorgement interest in contract law:

The traditional contract remedies, which are aimed at compensating the plaintiff for her loss, require information that tends to be available to the promisee-plaintiff. In contrast, the data required for establishing restitutionary recovery are much less accessible to her. In order to recover the promisor's profits, the promisee is required to submit evidence regarding another's affairs. Contractual rights that rely on information that can only be verified at a prohibitively high cost are inefficient.

Hanoch Dagan, The Law and Ethics of Restitution 275 (2003).

This argument is unpersuasive, because it is inappropriately asymmetrical. It is true that if a promisee sues for disgorgement damages, he will have difficulty observing the promisor's gains from breach. However, if a promisee sues for expectation damages, the promisor must be able to independently calculate the promisor's losses; and the promisor will have as much difficulty observing the promisee's losses as the promisee will have in observing the promisor's gains. Accordingly, if the promisee's difficulty in observing the promisor's gains would make it inefficient to protect the disgorgement interest, so too the promisor's difficulty in observing promisee's losses would make it inefficient to protect the expectation interest. In reality, of course, the law copes in both cases, in large part by affording discovery.

A related critique of Dagan's argument is made by Richard Brooks:

What's relevant ... is not that which is observed, but that which can be verified [in judicial proceedings]. A promisee may know with certainty her own value, but would nonetheless face high evidentiary costs if she cannot sufficiently establish this value in court; similarly, she may have only an approximate knowledge of the promisor's profits ..., but may be able to verify important aspects of it at low cost.

Richard R.W. Brooks, Efficient Performance Hypothesis 20 n. 33 (August 15, 2006) (unpublished manuscript on file with author). 
breaching promisor to retain his gains from breach. ${ }^{52}$ Some of the criticism was well developed, but was based on either principles of unjust enrichment, ${ }^{53}$ the theory that a promisee often has a property-like entitlement to performance, ${ }^{54}$ or both. An important and extensive critique along these lines was made by Daniel Friedmann, who argued for restitution of profits made from breach on the basis of an entitlement analysis: ${ }^{55}$

Contract relations may [] give rise to interests that come within the ambit of "property" for purposes of restitution....

Under the approach advocated here, the central issue in evaluating a claim for restitution of benefits obtained through a breach of contract can be presented as follows: When performance is promised under a contract, is the promisee "entitled" to it in such a way that if this performance is withheld, appropriated, or otherwise "taken," the promisee can be regarded as having been deprived of an interest that "belonged" to him?

Of course, moral intuitions are important here, as elsewhere in the law. Bargains consist of both express and implied terms. What terms can properly be implied in a contract depends partly on social morality, because a promisee's reasonable expectations depend partly on his reasonable beliefs

52. For example, George Palmer stated in his treatise on restitution:

Although the issue has gone largely unexplored, it has been commonly assumed that mere breach of contract will not make the defendant accountable for benefits thereby obtained, whether through dealings with a third person or otherwise .... But while the [contrary] principle has not gained general acceptance, and is not likely to do so, it cannot be wholly rejected. It has enough force to be brought into play when the whole circumstances of a case point to the conclusion that the defendant's retention of a profit is unjust. In time a principle of limited application may emerge, but it is too soon to say that this has occurred.

1 Palmer, supra note 5, at 438. Similarly, John Dawson stated:

[A]n alternative form of money judgment remedy .... could be used wherever the delivery of a specific asset or a defined course of action ... had been promised and through breach and resale to another the promisor was enabled to secure a readily measured gain. It may well be that the obstacle is nothing more than that well-known ailment of lawyers, a hardening of the categories.

John P. Dawson, Restitution or Damages?, 20 OHiо ST. U. L. REv. 175, 186-87 (1959).

53. See Gareth Jones, The Recovery of Benefits Gained From a Breach of Contract, 99 L.Q. REV. 443 (1983).

54. See James Edelman, Gain-Based Damages: Contract, Tort, Equity and IntelLECTUAL PROPERTY 149-89 (2002) (stressing cases in which the promisee has a "legitimate interest in performance," although also giving some attention to efficiency considerations). A related critique was that there was not sufficient reason for distinguishing, in regard to disgorgement, between property and fiduciary law, on the one hand, and contract law, on the other. See Lionel D. Smith, Disgorgement of the Profits of Breach of Contract: Property, Contract, and "Efficient Breach," 24 CAN. BUS. L.J. 121 (1995).

55. Daniel Friedmann, Restitution of Benefits Obtained through the Appropriation of Property or the Commission of a Wrong, 80 CoLum. L. Rev. 504, at 513-527 (1980).

56. Id. at 513, 515. Friedmann made parallel arguments in Daniel Friedmann, The Efficient Breach Fallacy, 18 J. LeGAL STud, 1 (1989), and Daniel Friedmann, Restitution for Wrongs: The Measure of Recovery, 79 TEX. L. REv. 1879 (2001) [hereinafter Friedmann, Restitution for Wrongs]. Friedmann's arguments led to protection of the disgorgement interest by the Israel Supreme Court. FH 20/82 Adras v. Harlow \& Jones Gmbh [1988] IsrSC 42(1) 221, reprinted in 3 Restitution L. REv. 235 (1995). 
concerning the moral obligations that a given type of promise conventionally entails. Moreover, when protection of the disgorgement interest is given, a promisor who wishes not to perform has an incentive to renegotiate with the promisee rather than to unilaterally breach. This incentive has an efficiency dimension, but it also has a moral dimension. A promise is a morally binding commitment. That doesn't mean that a promisor can never morally fail to perform a promise. For example, failure to keep a promise may be morally excused because the breach is inadvertent or performance is impracticable. However, where nonperformance would not be morally excused, a promisor who wishes not to perform owes a moral duty of respect to the promisee to seek a mutual accommodation, rather than to unilaterally breach and thereby convert the promisee from a voluntary actor to an involuntary litigant. An idea of this sort was expressed by Judge Posner, in a different context, in Taylor v. Meirick:

It is true that if the [copyright] infringer makes greater profits than the copyright owner lost, because the infringer is a more efficient producer than the owner or sells in a different market, the owner is allowed to capture the additional profit even though it does not represent a loss to him. It may seem wrong to penalize the infringer for his superior efficiency and give the owner a windfall. But it discourages infringement. By preventing infringers from obtaining any net profit it makes any would-be infringer negotiate directly with the owner of a copyright that he wants to use, rather than bypass the market by stealing the copyright and forcing the owner to seek compensation from the courts for his loss. Since the infringer's gain might exceed the owner's loss, especially as loss is measured by a court, limiting damages to that loss would not effectively deter this kind of forced exchange. $^{57}$

Protection of the disgorgement interest is also sometimes required to prevent unjust enrichment, and the principles of unjust enrichment overlap with the principles of morality. The law does not require everyone who is benefited by another's action to restore the value of the benefit. Only benefits whose retention would result in unjust enrichment must be restored. Restatement Second section 344(c) conventionally defines the restitution interest in contract law as the promisee's interest in having restored to him any benefit that he has conferred on the promisor. For the most part, the categories of cases in which the disgorgement interest should be protected in contract law do not involve such a benefit, at least not in an obvious way. If they did, protection of the disgorgement interest would be unnecessary, because the cases could be decided by protection of the restitution interest. Nevertheless, in certain categories of cases protection of the disgorgement interest is a necessary or important instrument to prevent unjust enrichment, because the promisor's unjust retention of a benefit, although real, may not be obvious.

But despite the moral implications of disgorgement, and the significance of unjust-enrichment principles in some categories of disgorgement cases, 
contract law is primarily about efficiency. Although the expectation measure provides efficient incentives for precaution and perform-or-breach decisions in most cases (or would, if expectation damages were perfect), it does not provide efficient incentives for those decisions in all cases. In the balance of this Part, I will show that protection of the disgorgement interest in contract law is most often justified not simply on moral grounds or to prevent unjust enrichment, but on efficiency grounds, because in certain categories of cases a rule that protects the disgorgement interest is necessary to provide efficient incentives to the promisor and to effectuate contracts.

\section{B. Cases in which the Promisee Has Bargained for the Promisor's Gain from Breach}

In some cases, efficiency requires the disgorgement interest to be protected in contract law because the promisee has bargained for the gain that the promisor has made through breach. Ironically, the leading such case is the poster-child for the theory of efficient breach, that is, the Overbidder Paradigm.

As shown in the discussion of that theory in Section II.C, it is normally implied in a contract for the sale of a commodity that the seller will neither seek out nor accept offers from overbidders. Furthermore, a buyer will normally pay an implicit premium for that promise. At the time a contract for the sale of a differentiated commodity is made, the buyer and the seller know that an overbid might later be made. ${ }^{58}$ Just as the buyer takes the negative risk that the value of the commodity may fall before delivery, so too the buyer takes, and the seller forgoes, the positive or upside risk that an overbidder may turn up. Because the buyer and the seller know this, the buyer will need to pay the seller an implicit premium for forgoing the positive risk. The amount of this premium will be the expected value of an overbid, based roughly on a probability-weighted average of potential overbid prices. To put this differently, if the seller is economically rational, her price will include a premium paid by the buyer for the seller's implied promise to take the contracted-for commodity off the market-a premium equal to the reduction in price that the buyer would demand for giving the seller a right to resell to an overbidder.

58. As explained by Alan Schwartz:

[Markets for unique goods] often are well organized; the antique market provides an example. Such markets have two distinguishing features. First, they are usually characterized by greater price dispersion than obtains in the market equilibria for roughly fungible goods. In addition, sellers of unique goods face a lower "rate of arrival" of potential buyers than do sellers of roughly fungible goods. These two phenomena are related; a high "buyer arrival" rate implies extensive comparison shopping among firms, whereas the degree of price dispersion a market can sustain varies inversely with the amount of comparison shopping ....

[A seller of differentiated] goods consequently has grounds to believe that the offers he receives are to some extent random, and that later offers could be much higher than earlier ones.

Alan Schwartz, The Case for Specific Performance, 89 YALE L.J. 271, 281 (1979). Schwartz uses the term "unique," rather than "differentiated," but it is clear from his text that he is referring to nonhomogeneous - that is, differentiated goods. 
In such cases, therefore, if the seller breaches and sells to an overbidder, what looks like disgorgement is actually a form of expectation damages, because the promisor has paid for the right to any profit derived from selling to the overbidder. Making a forward contract for the sale of a differentiated commodity reflects a decision by the seller, embodied in a binding commitment, that her best bet is to take the buyer's present offer, including the implicit premium, rather than waiting for a possible higher offer in the future. If the seller accepts a higher offer, she is reneging on her bet. The buyer's bargained-for payoff is the seller's gain from breach.

This point is brought out in a line of cases concerning contracts for the sale of real property in which the seller breaches to sell to an overbidder, and the buyer brings suit. Some cases hold that on those facts the buyer is only entitled to the difference between the contract price and the market price, and that the price paid by the overbidder is evidence of market price but is not determinative. ${ }^{59}$ In most cases, however, the courts have either treated the resale price as virtually conclusive evidence of market price, ${ }^{60}$ which is economically equivalent to granting disgorgement, or have granted disgorgement directly. ${ }^{61}$ For example, in Coppola Enterprises, Inc. v. Alfone, ${ }^{62}$ Alfone contracted with Coppola to purchase a single-family home, "Unit 53," to be constructed by Coppola. The purchase price was $\$ 105,690$. The contract provided that the closing was to occur after ten days' written notice from Coppola. Closing was projected for winter 1978-79, but due to construction delays, closing was rescheduled for late summer 1980. At that point, Alfone was unable to acquire the necessary financing within the time required, and requested additional time. Coppola refused, and subsequently resold Unit 53 for $\$ 170,000$. The trial court found that Coppola failed to exercise good faith by refusing Alfone a reasonable time to close and terminating the contract, and awarded Alfone $\$ 64,310$ - Coppola's profit on the resale. The Florida Supreme Court affirmed, holding that Alfone was entitled to disgorgement whether or not Coppola acted in bad faith:

Coppola was obligated to sell Unit 53 to Alfone under their contract . . . . Alfone was entitled to a reasonable time in which to acquire the funds to pay the balance due on the property. Once Coppola breached its contract with Alfone and was unable to perform due to the sale of Unit 53 to a sub-

59. E.g., Grummel v. Hollenstein, 367 P.2d 960 (Ariz. 1962); Kemp v. Gannett, 365 N.E.2d 1112 (Ill. App. Ct. 1977); Reed v. Wadsworth, 553 P.2d 1024, 1036 (Wyo. 1976); cf. Triangle Waist Co. v. Todd, 119 N.E. 85, 86 (N.Y. 1918) (Cardozo, J.) ("The price received upon a genuine sale either of property or of services is some evidence of value."); Murphy v. Lifschitz, 49 N.Y.S.2d 439, 441 (1944), aff'd per curiam, 63 N.E.2d 26 (N.Y. 1945) (sale-of-goods case).

60. E.g., Mercer v. Lemmens, 40 Cal. Rptr. 803, 807 (1964); Phelps v. O'Malley, 511 N.E.2d 974 (Ill. App. Ct. 1987); Newman v. Cary, 466 So. 2 d 774 (La. Ct. App. 1985).

61. E.g., Defeyter v. Riley, 671 P.2d 995 (Colo. Ct. App. 1983); Seaside Cmty. Dev. Corp. v. Edwards, 573 So. 2d 142 (Fla. Dist. Ct. App. 1991); Middleton v. Crowder, 563 So. 2d 94 (Fla. Dist. Ct. App. 1990); Colby v. Street, 178 N.W. 599 (Minn. 1920); Timko v. Useful Homes Corp., 168 A. 824 (N.J. Ch. 1933); Taylor v. Kelly, 56 N.C. (3 Jones Eq.) 240, 245 (1857).

62. 531 So. 2d 334 (Fla. 1988). 
sequent purchaser, Alfone was entitled to damages equal to Coppola's profits from the sale.

We need not address whether Coppola's decision to sell Unit 53 to a subsequent purchaser involved bad faith. Resolution of that issue is not dispositive here.... [T] he buyer is entitled to these damages whether the sale to the subsequent purchaser involved bad faith or was merely the result of a good-faith mistake. A seller will not be permitted to profit from his breach of a contract with a buyer, even absent proof of fraud or bad faith, when the breach is followed by a sale of the land to a subsequent purchaser. $^{63}$

Disgorgement in such cases is sometimes rationalized as consistent with the position of Restatement Second on the theory that because a realproperty buyer has a right to specific performance, he is the "equitable owner" of the property and the seller is a "trustee," so that trust and property rules come into play. ${ }^{64}$ This kind of reasoning is hypertechnical and brittle, and did not drive the reasoning in Coppola. Farnsworth pointed out that treating a seller of real property as a trustee "would, if taken literally, lead to extraordinary results by subjecting the seller to all of the restraints imposed on a trustee.",6s

The trust or property theory was also rejected in favor of a disgorgement theory in Laurin v. DeCarolis Construction Co. ${ }^{66}$ decided by the Massachusetts Supreme Judicial Court in an opinion by Judge Robert Braucher. In March 1971, the Laurins agreed to purchase, for $\$ 26,900$, a home that DeCarolis was then constructing. The home was situated on a well-wooded lot. Prior to the closing, the Laurins found that after the contract had been signed, DeCarolis had bulldozed many of the trees on the property, apparently for its own use. The Laurins ordered DeCarolis to desist, but DeCarolis continued to bulldoze trees and also removed gravel and loam worth $\$ 6,480$. The Laurins paid the purchase price at the closing, and then sued DeCarolis for the value of the trees, gravel, and loam that DeCarolis had removed.

The case was tried by a master, who concluded that the Laurins were the "equitable owners" of the property from and after the signing of the agreement, so that DeCarolis had unlawfully converted the trees, gravel, and loam. In other words, the master reasoned that the Laurins were entitled to disgorgement under a property theory. The Massachusetts Supreme Judicial Court rejected this reasoning, on the ground that under Massachusetts law "the rights of the purchaser" of real property prior to closing "are contract rights rather than rights of ownership of real property.", ${ }^{, 67}$ Accordingly, the Court concluded, this "case must be decided, not as ... [an] action for

\footnotetext{
63. Id. at $335-36$.

64. See, e.g., Timko, 168 A. 824.

65. Famsworth, supra note 4, at 1364.

66. 363 N.E.2d 675 (Mass. 1977).

67. Id. at 678 .
} 
injury to or conversion of property, but as a claim for a deliberate and wilful breach of contract." ${ }^{, 68}$

This left the contract theory. The problem was that taking the trees, gravel, and loam had not diminished the value of the property. Therefore, although DeCarolis had made a gain from breach, the Laurins had not suffered a loss. Nevertheless, the Court held that the Laurins were entitled to disgorgement, because DeCarolis should not be allowed to retain its gains from a willful breach of contract:

Particularly where the defendant's breach is deliberate and wilful, we think damages limited to diminution in value of the premises may sometimes be seriously inadequate. "Cutting a few trees on a timber tract, or taking a few hundred tons of coal from a mine, might not diminish the market value of the tract, or of the mine, and yet the value of the wood or coal, severed from the soil, might be considerable. The wrongdoer would, in the cases instanced, be held to pay the value of the wood and coal, and he could not shield himself by showing that the property from which it was taken was, as a whole, worth as much as it was before." This reasoning does not depend for its soundness on the holding of a property interest, as distinguished from a contractual interest, by the plaintiffs. Nor is it punitive; it merely deprives the defendant of a profit wrongfully made, a profit which the plaintiff was entitled to make. ${ }^{69}$

\section{Disgorgement in Lieu of Specific Performance}

The disgorgement interest should also be protected in cases in which the promisee would have been awarded specific performance if he had been able to bring suit before the promisor's wrongful action put that remedy beyond reach-for example, by selling to a bona fide purchaser. The disgorgement interest should be protected in such cases to protect the integrity of contract law: unless disgorgement is awarded in such cases, a promisor could subvert the right to specific performance simply by completing an irreversible breach before the promisee can get to court. ${ }^{70}$ There is also an efficiency reason for a rule protecting the disgorgement interest under these circumstances. Because contract law is largely driven by efficiency considerations, it is fair to presume that if specific performance is awarded in a given type of case, normally that is because it is efficient to do so. If in such a case specific performance cannot be awarded solely because the promisor has put that remedy beyond the promisee's reach, the disgorgement interest should be protected on the ground that disgorgement better approximates specific performance, which is presumptively efficient, than does the expectation measure.

68. Id.

69. Id. at 678-79 (citation omitted).

70. See Edward Yorio, In Defense of Money Damages for Breach of Contract, 82 Cotum. L. Rev. 1365, 1402 n.196 (1982). 
The leading case against protection of the disgorgement interest, U.S. Naval Institute v. Charter Communications, Inc.," was incorrectly decided, partly because the court failed to grasp this point. Tom Clancy had written The Hunt for Red October. The book was published in hardcover by Naval Institute Press, which also held the copyright. On September 14, 1984, Naval licensed Berkley Publishing Group to publish the paperback edition of the book. Paragraph 2 of the licensing contract provided that the term of the license "will begin on the date written above" and continue until five years after the date of Berkley's first publication. Paragraph 4 provided that Berkley would not publish the paperback edition sooner than October 1985.

The Hunt for Red October unexpectedly turned out to be a huge bestseller. Berkley shipped the paperback edition early, and retail sales of the paperback began on September 15, 1985, rather than in October. The paperback sales were so large that before the end of September the book was near the top of paperback bestseller lists. Naval brought suit against Berkley in federal court for copyright infringement and breach of contract.

The case went through two appeals. On the first appeal, the Second Circuit held that Berkley had breached the contract by causing voluminous paperback retail sales before October 1985 , and remanded the case for entry of a judgment awarding Naval appropriate relief. On remand, Naval claimed that Berkley's sales of the paperback edition prior to October 1985 infringed Naval's copyright, and sought a judgment for Berkley's profits on those sales. Then-District Court Judge Pierre Leval found that Naval's copyright had been infringed by the pre-October sales, and awarded damages based on two elements: (1) Naval's losses from Berkley's wrongful pre-October publication, and (2) disgorgement of Berkley's profits from the infringement.

Judge Leval calculated the first element, Naval's losses from Berkley's wrongful pre-October publication, as the profits that Naval would have earned from hardcover sales in September 1985 if the paperback edition had not then been wrongfully offered for sale that month. He awarded Naval $\$ 35,380$ on this head. As to the disgorgement claim, Judge Leval held that Naval was entitled to the profits that Berkley made from sales to customers who would not have bought the paperback but for the fact that it became available in September. He awarded Naval $\$ 7,760$ on this head.

The logic of Judge Leval's damages analysis can be understood as follows. Book buyers can be divided into Spenders, Savers, and Supersavers. Spenders always buy the hardcover edition of a book, even if a paperback edition has already been published. Savers buy the hardcover edition of a book if but only if the paperback edition has not yet been published; if the paperback edition has been published, Savers buy the paperback. Supersavers buy only paperbacks, and therefore always wait until the paperback edition is available.

Premature publication of the paperback edition neither affected Naval's sales to Spenders or Supersavers, nor produced a gain from breach as a result of Berkley's sales to those buyers: Spenders bought the hardcover 
edition anyway, and Supersavers wouldn't have bought the hardcover edition in any event.

The situation regarding Savers, however, was different. Because Savers would have bought the hardcover edition in September if the paperback edition had not yet been published, premature publication of the paperback edition caused Naval to lose the profits it would have made on sales of the hardcover edition to Savers in September. Correspondingly, premature publication resulted in gains from breach for Berkley in the amount of the profits from sales of the paperback edition to Savers in September: except for the premature publication, Savers would have purchased the hardcover edition that month, and then would have had no interest in purchasing the paperback edition when it appeared in October.

On appeal from Judge Leval's decision, the Second Circuit began with the copyright-infringement issue. The court held that Berkley had not infringed Naval's copyright. Paragraph 2 of the contract provided that Berkley's license took effect on "the date written above." The only date written above Paragraph 2 was the heading-"Agreement made this 14th day of September 1984." The court concluded that the license therefore began on that date. Accordingly, the court held, Berkley's publication in September 1985 did not constitute copyright infringement.

The Second Circuit then turned to a breach-of-contract analysis. It affirmed the award of $\$ 35,380$ based on Naval's lost profits on the sales it would have made to Savers who would have bought the hardcover edition in September but for Berkley's breach, because even if Berkley had not infringed Naval's copyright, it had breached the contract. However, the court held, Judge Leval's $\$ 7,760$ award based on Berkley's gains from breach from its sales to Savers in September was improper because the general principle in contract law is that a promisee can recover only its losses, not the promisor's gains.

Naval Institute illustrates the shaky nature of the distinction between property rights and contract rights in regard to disgorgement, because resolution of the property-law question-when did Berkley's license begindepended entirely on an interpretation of the contract. Paragraph 2 of the contract provided, somewhat cryptically, that the license began "on the date written above." The Second Circuit concluded that the license began on September 14,1984 , the date set out in the heading of the contract, because that was the only date that appeared before Paragraph 2 . This interpretation is not entirely convincing. The license was to last until five years after Berkley's first publication, which could properly be made only in October 1985. Why would Naval Institute license Berkley for almost a year during which Berkley had no right to publish? Why wouldn't the license begin when Berkley first had a right to publish? Indeed, that is just how Judge Leval construed the contract.

Suppose the Second Circuit had concluded that Berkley did not have a license to publish the paperback edition in September 1985, so that publication in September infringed Naval's copyright. Presumably in that case the court would have allowed Naval to recover Berkley's gains from premature 
publication, because premature publication would have violated Naval's property interest in its copyright. In contrast, because the court concluded that Berkley's license took effect in September 1984, Berkley's only wrong was a breach of contract, which in the court's view did not provide a basis for disgorgement. It seems scholastic, however, to draw such a sharp distinction between contract rights, on the one hand, and property rights that wholly depend upon contract rights, on the other. To put this differently, even if the Second Circuit's interpretation of the contract was correct, once the wrongfulness of the September publication was established, why should the availability of disgorgement turn on whether the wrongful publication fit into a property box or a contract box? The decision was also incorrect because Naval would almost certainly have been entitled to enjoin Berkley from publishing the paperback edition in September if Naval Institute had time to obtain the injunction before the wrongful publication occurred. The disgorgement interest should have been protected for that reason alone.

\section{Disgorgement as a Surrogate for Expectation Damages}

Still another category in which disgorgement should be utilized consists of cases in which the disgorgement measure serves as a surrogate for the expectation measure, in the same way that the reliance measure sometimes serves as a surrogate for the expectation measure when expectation damages are too uncertain to calculate. ${ }^{72}$ Naval Institute, if properly considered, might well have fallen into that category. In deciding that case, the court failed to consider the purpose of the provision concerning the date of publication by Berkley. Because the court did not consider that issue, we cannot know the purpose. However, we do know that Naval believed that it was in its interests to not have the paperback edition published before October, and we can easily imagine why that was so. For example, in the publishing industry retailers can return unsold books to the publisher for full credit. Therefore, Naval would want to know when the paperback edition would be published so that it could adjust its printing schedule and not be stuck with excessive returns of the hardcover edition. Naval might also have wanted to adjust the timing of its promotional efforts, so that Berkley would not free ride on advertising by Naval that would do little or nothing to promote sales of the hardcover edition once the paperback edition was on the market. Berkley's breach threw a monkey wrench into these or other types of planning, but the resulting planning losses would be very difficult to establish with sufficient certainty to qualify for expectation damages. The prospect that the disgorgement interest will be protected serves an important efficiency interest in cases like these, where expectation damages are likely to be unrecoverable on the ground of uncertainty. In the absence of that prospect, there would be insufficient incentives for the promisor to perform in such cases,

72. See, e.g., Sec. Stove \& Mfg. Co. v. Am. Ry. Express Co., 51 S.W.2d 572 (Mo. Ct. App. 1932). 
especially where, as was likely true in Naval Institute, reliance damages would also be difficult to measure.

In this connection, there is a line of cases concerning damages where the defendant has wrongfully competed with the plaintiff, in breach of a noncompete agreement or of an agreement to give the plaintiff exclusive territorial rights. In many or most of these cases, the courts have awarded the plaintiff damages based on the defendant's profits. ${ }^{73}$ In some of these cases the courts have protected the disgorgement interest as such. ${ }^{74}$ In others, the disgorgement measure has been used as a surrogate for the expectation measure. ${ }^{75}$ Admittedly, in the latter cases-or in the variant of Naval Institute in which disgorgement should be used as a surrogate to measure Naval's uncertain planning losses-the court does not protect the disgorgement interest as such. However, the difference between using the disgorgement measure to protect the expectation interest and using it to protect the disgorgement interest is not very robust. ${ }^{76}$

\section{E. Bargains Designed to Serve Interests Other Than Profit-making}

Most bargains are made for profit-making purposes, but some are not. Often, bargains of the latter type can best or only be effectuated, and correct incentives for the promisor can best or only be provided, by protection of the disgorgement interest. Two leading examples are strikingly similar cases decided by the highest courts of the United States and Great Britain, Snepp v. United States ${ }^{77}$ and Attorney General v. Blake. ${ }^{78}$

In Snepp, decided by the United States Supreme Court, Frank Snepp had been an employee of the Central Intelligence Agency. As a condition of his employment, Snepp had signed a contract in which he promised that he would " "not ... publish ... any information or material relating to the term of [his] employment ... without specific prior approval by the Agency.',"79 After Snepp left the CIA, he published a book about CIA activities in South

73. See, e.g., Cincinnati Siemens-Lungren Gas Illuminating Co. v. Western Siemens-Lungren Co., 152 U.S. 200 (1894); Unita Oil Ref. Co. v. Ledford, 244 P.2d 881 (Colo. 1952); Automatic Laundry Serv., Inc. v. Demas, 141 A.2d 497 (Md. 1958); Oscar Barnett Foundry Co. v. Crowe, 86 A. 915 (N.J. 1912); Y.J.D. Rest. Supply Co. v. Dib, 413 N.Y.S.2d 835 (N.Y. Sup. Ct. 1979); Buxbaum v. G.H.P. Cigar Co., 206 N.W. 59 (Wis. 1925). But see Vt. Elec. Supply Co. v. Andrus, 373 A.2d 531 (Vt. 1977).

74. See, e.g., Cincinnati Siemens-Lungren, 152 U.S. 200; Automatic Laundry Serv., 141 A.2d 497; Oscar Barnett, 86 A. 915 ; Y.J.D. Restaurant Supply, 413 N.Y.S.2d 835.

75. See, e.g., Unita Oil, 244 P.2d 881; Buxbaum, 206 N.W. 59.

76. See, for instance, Unita Oil, 244 P.2d 881, in which the court first said that the promisor's profits may make possible a reasonable estimate of the promisee's lost profits, but then went on to hold that the promisee could simply recover the promisor's profits.

77. 444 U.S. 507 (1980).

78. [2001] 1 A.C. 268, (2000) 4 All E.R. 385 (UKHL).

79. Snepp, 444 U.S. at 508 (quoting Petition for Writ of Certiorari, Snepp, 444 U.S. 507 (No. 78-1871)). 
Vietnam that occurred during the term of his employment. The book contained no classified information, but Snepp published the book without having submitted it to the CIA for prior approval.

The Government sued Snepp for disgorgement of his profits on the book. The Supreme Court held that Snepp was obliged to disgorge the profits because he did not submit the book for prior approval, as he had contracted to do. The Court rested its opinion in part on the theory that "Snepp's employment with the CIA involved an extremely high degree of trust," and that Snepp violated that trust. ${ }^{80}$ This rhetoric, taken at face value, makes Snepp look like a breach-of-fiduciary-duty case. However, the case did not involve the breach of a fiduciary duty imposed by law, such as the duty of a fiduciary not to transact with his beneficiary on unfair terms. Rather, Snepp was liable because, and only because, he breached the contract. Moreover, although the Court's opinion was at least nominally based on Snepp's relationship of trust, it was also explicitly based on the Court's view that no remedy other than disgorgement would effectuate the contract. In this regard, the Court said that although the Government was likely harmed by Snepp's book, proof of that harm would be too difficult, and the Government could not pursue other remedies, such as nominal damages, "without losing the benefit of the bargain it seeks to enforce." Snepp was at least as much a contract-law case as a fiduciary-duty case, and really more of a contract-law case than a fiduciary-duty case.

Attorney General v. Blake, decided by the English House of Lords, was extraordinarily similar to Snepp. George Blake, like Snepp, had been a member of his Government's intelligence service. Blake, like Snepp, had made a contract at the outset of his employment that restricted his rights to publish: "I undertake not to divulge any official information gained by me as a result of my employment, either in the press or in book form. I also understand that these provisions apply ... after employment has ceased." ${ }^{82}$ Blake, like Snepp, had broken the contract by publishing a book relating to his activities as a secret-intelligence officer. Blake's book, like Snepp's book, contained no information that was confidential at the time of publication. The British Government, like the American Government, sought disgorgement of Blake's profits from the book. The House of Lords, like the Supreme Court, granted that remedy.

In Snepp, the Supreme Court employed fiduciary-like rhetoric, at least in part. In Blake, the House of Lords did not. Indeed, just the reverse. At the trial, the British Government had rested its case exclusively on the theory that in writing and publishing his book, Blake had violated his fiduciary duties to the Government. The trial court held, however, that although former members of the intelligence service owe a lifelong fiduciary duty of non-disclosure in respect of secret and confidential information, they owe

80. Id. at $510-511$.

81. Id. at 514 .

82. Blake, 4 All E.R. at 390. 
no further fiduciary duty. The House of Lords did not challenge this conclusion. As a result, the Lords could not and did not rest their decision on fiduciary duties, because Blake did not use secret or confidential information. Instead, the Lords explicitly addressed, in a very sophisticated way, whether contract law should protect the disgorgement interest.

Lord Nicholls wrote the lead opinion in the case. He began by pointing out that although the general principle is that the purpose of damages is to compensate for injury, the law makes exceptions to that principle:

Earl of Halsbury L.C. famously asked in The Mediana ... that if a person took away a chair from his room and kept it for 12 months, could anybody say you had a right to diminish the damages by showing that I did not usually sit in that chair, or that there were plenty of other chairs in the room? To the same effect was Lord Shaw's telling example in Watson, Laidlaw \& Co. Ltd. v. Pott, Cassels, and Williamson. It bears repetition:

'If $\mathrm{A}$, being a liveryman, keeps his horse standing idle in the stable, and $\mathrm{B}$, against his wish or without his knowledge, rides or drives it out, it is no answer to A for B to say: "Against what loss do you want to be restored? I restore the horse. There is no loss. The horse is none the worse; it is the better for the exercise."

Against that background, Lord Nicholls turned to the remedies available for breach of contract. He showed that courts deciding contract-law cases have recognized the interest of a promisor in performance itself, both by granting specific performance and by requiring disgorgement of the wrongdoer's gain, where appropriate:

The law recognises that a party to a contract may have an interest in performance which is not readily measurable in terms of money. On breach the innocent party suffers a loss. He fails to obtain the benefit promised by the other party to the contract. To him the loss may be as important as financially measurable loss, or more so. An award of damages, assessed by reference to financial loss, will not recompense him properly. For him a financially assessed measure of damages is inadequate. ${ }^{84}$

From that starting point, Lord Nicholls went on to lay down the principle that contract law should protect the disgorgement interest by making the remedy of disgorgement available in appropriate cases:

[The] cases illustrate that circumstances do arise when the just response to a breach of contract is that the wrongdoer should not be permitted to retain any profit from the breach....

My conclusion is that there seems to be no reason, in principle, why the court must in all circumstances rule out an account of profits as a remedy for breach of contract .... Remedies are the law's response to a wrong (or, more precisely, to a cause of action). When, exceptionally, a just response to a breach of contract so requires, the court should be able to grant the

83. Id. at 391 (citations omitted).

84. Id. at 394 . 
discretionary remedy of requiring a defendant to account to the plaintiff for the benefits he has received from his breach of contract. In the same way as a plaintiff's interest in performance of a contract may render it just and equitable for the court to make an order for specific performance or grant an injunction, so the plaintiff's interest in performance may make it just and equitable that the defendant should retain no benefit from his breach of contract. $^{85}$

Snepp and Blake were correctly decided. The contractual purpose of each government in these cases was the management of potentially sensitive information. That purpose could not be readily served by protecting the expectation interest, because the information had no market value and the Governments suffered no economic loss by its publication. ${ }^{86}$ Specific performance was not an available remedy because the contracts had already been irremediably broken. Reliance damages would not be of use because the governments had not incurred demonstrable costs in reliance. Restitutionary damages would not be of use because there was no benefit conferred on the defendants by the Governments that could be recovered under the law of restitution. Accordingly, as the Supreme Court emphasized in Snepp, the best and perhaps only way to effectuate the contracts was to protect the disgorgement interest. ${ }^{87}$ Therefore, as in Snepp and Blake, courts should protect the disgorgement interest in the case of bargain contracts that are not designed for profit-making purposes, so as to give the promisor in such contracts efficient incentives to perform, and to effectuate contracts of this type.

85. Id. at 397; see also Bank of Am. Can. v. Mut. Trust Co., [2002] 2 S.C.R. 601 (Can.), discussed in Mitchell McInnes, Restitutionary Damages for Breach of Contract: Bank of America Canada v. Mutual Trust Co., 37 Canadian Bus. L.J. 125 (2002); FH 20/82 Adras v. Harlow \& Jones Gmbh [1988] IsrSC 42(1) 221, reprinted in 3 RestiTution L. Rev. 235 (1995) (protecting disgorgement interest in contract law in a mixed common law/civil law jurisdiction); $c f$. Experience Hendrix LLC $v$. PPX Enters. Inc., 1 All E.R. 830 (Ct. App. 2003) (ordering disgorgement of part of the promisor's profits, based on what the promisor would have had to pay for a modification).

86. David Fox, Case and Comment, Restitutionary Damages to Deter Breach of Contract, 60 CAmbridge L.J. 33, 34 (2001). Moreover, as John McCamus has pointed out, if Blake had submitted his manuscript for approval, and the Crown did not give its approval, Blake would not have published his book, and therefore would have earned no royalties, so that performance of Blake's promise might not have economically benefited the Crown. See John D. McCamus, Disgorgement for Breach of Contract: A Comparative Perspective, 36 LoY. L.A. L. Rev. 943, 947-48 (2003).

87. Punitive damages might seem to be an alternative, but most courts will not grant punitive damages in the absence of actual losses. More important, punitive damages would be less socially desirable than disgorgement because unlike disgorgement, punitive damages do not have a one-toone relationship with either the promisee's loss or the promisor's gain. A promisor might have a legitimate moral objection concerning the imposition of punitive damages that are out of proportion to either her gain or the promisee's loss, but a promisor has no moral ground for complaining about a judgment that merely requires her to give up the gain she made from committing a wrong. As stated in Snepp, "since the remedy [of disgorgement] reaches only funds attributable to the breach, it cannot saddle the [defendant] with exemplary damages out of all proportion to his gain." Snepp, 444 U.S. at 515-16. Although disgorgement is sometimes itself viewed as a penalty, depriving a person of what he has gained by a wrongful act hardly seems penal. Cf. Jones, supra note 53, at 456 ("[T]o be deprived of what you have [improperly] gained can never be a penal liability."). 


\section{F. Externalities}

The purpose of some contracts is primarily to create an externality, that is, to benefit the public, or some segment of the public, rather than the contracting parties. In such cases, protection of the promisee's disgorgement interest will often be the best or only way to effectuate the contract and to give the promisor efficient incentives to perform, because the promisee may have little or no financial losses from the promisor's breach, and the public, or the segment of the public, may not have standing to bring suit.

For example, in British Motor Trade Ass'n v. Gilbert, ${ }^{88}$ the British Trade Association had created an arrangement with new-car dealers that was designed to hold down the inflation of new-car prices during a new-car shortage after World War II. Under the arrangement, new-car dealers required new-car buyers to enter into a contract with the Association. Under the contract, the buyer agreed that if he wanted to resell the car within two years he would sell it only to the Association, at the original sale price minus a stipulated rate of depreciation. The Association, in turn, agreed that it would buy the car at that price and resell the car at the price that it paid.

Gilbert entered into the contract with the Association, and bought a new car, but within two years he sold the car on the black market at a large profit. The Association sued for disgorgement of the profit. Although Gilbert was in breach, the Association had no expectation damages, because if Gilbert had performed the contract by selling the car to the Association, the Association would have been required to resell the car at the price it paid. However, the purpose of the contract was not to benefit either the British Trade Association or new-car dealers-at least not in any direct, commercial way. Rather, the purpose of the contract was to create an externality that would benefit the general public, by preventing an inflationary black market in cars. The best or only way to effectuate this purpose, and to give new-carbuyers efficient incentives to perform, was to require Gilbert to disgorge the profit he had made on resale. The court properly so held.

\section{G. Disgorgement of Costs Saved by Breach}

Protection of the disgorgement interest is also necessary to effectuate a contract, to provide efficient incentives for precaution and performance, and to prevent unjust enrichment, where a promisor breaches in a way that reduces her costs but does not cause an equivalent loss to the promisee. I will consider two types of such cases.

1. Skimped services. In one type, sometimes known as skimpedservices cases, $A$ agrees to provide services to or for $B$ on an as-needed basis during a stated period and, in that connection, to make designated facilities and personnel available, during the period, to perform or support the services. $B$, in turn, agrees to pay $A$ a flat amount, rather than paying for whatever services are actually needed and rendered during the 
period. As things turn out, $A$ did not maintain facilities and personnel at the agreed level, but nevertheless had enough facilities and personnel to perform all the services that $B$ actually needed during the period. For example, suppose that $A$, a marine salvor, agrees with $B$, a shipping company, that in exchange for a flat payment of $\$ 1,000,000, A$ will station rescue tugboats at strategic locations around the world, during a one-year period, to come to the aid of $B$ 's vessels in distress. During the one-year period $A$ does not station all tugboats he promised, but $B$ suffers no loss because none of $B$ 's vessels fall into distress.

In this type of case, the purpose of the contract is to assure that the promisor will maintain the promised facilities and personnel in place. Expectation damages give the promisor insufficient incentives to perform, because the promisee will incur no loss as a result of the breach if, despite the breach, the promisor is able to provide all the services that the promisee ends up actually needing. In contrast, a rule that in such cases contract law will protect the disgorgement interest, measured by the promisor's saved costs, will give the promisor efficient incentives to perform and therefore will effectuate the contract. Moreover, in the absence of disgorgement the promisor will be unjustly enriched because she will have been paid for a performance that she did not render.

Accordingly, if in such a case the promisee has paid the promisor in advance, the promisee should be entitled to disgorgement of the promisor's saved costs. If the promisee has not paid the promisor in advance, the saved costs should be deducted from the contract price. ${ }^{89}$

2. Diminished-value cases. A related type of case of case arises where a promisor who has agreed to perform services renders a defective performance, or fails to perform at all, and the cost of remediating the performance exceeds the value of the remediation. The normal measure of damages for the rendition of defective services, known as cost-ofcompletion damages, is based on the cost of remediating the defective performance. Under this measure, the promisee is entitled to recover the amount that he must pay a substitute contractor to complete the promisor's obligations. Under a less-often-used expectation measure, known

89. A contrary result was incorrectly reached in City of New Orleans v. Firemen's Charitable Ass'n, 9 So. 486 (La. 1891). There, the promisor had agreed to provide a certain number of firemen, and certain lengths of hose and pipe, to fight fire in the City during a given period. After the end of the period, the plaintiff discovered that the number of firemen and the lengths of hose and pipe fell short of the amount required by the contract. The court declined to impose damages, on the ground that the City suffered no losses as a result of the shortfalls. In Attorney General v. Blake (1998) I All E.R. 833 (CA), the English Court of Appeal properly criticized City of New Orleans, stating, "Justice surely demands an award of substantial damages in such a case, and the amount of expenditure which the defendant has saved by the breach provides an appropriate measure of damages." $I d$. at 845. In any event, the precedential effect of City of New Orleans in the common law is very limited, because Louisiana is a civil-law jurisdiction. In Coca-Cola Bottling v. Coca-Cola, 988 F.2d 286, 406-10 (3d Cir. 1993), Coca-Cola skimped in supplying syrup to bottlers, by making the syrup with a less costly sweetener than was contractually required. The bottlers suffered no loss because the syrup that was actually supplied was of the same quality as the promised syrup and was equally acceptable to consumers, and the bottlers had no lost sales as a result of the substitution. The court held that the bottlers could not recover Coca-Cola's saved costs. 
as diminished-value damages, the promisee is entitled to the difference between the value of what he was promised and the value of what he actually received.

Use of the diminished-value measure, rather than the cost-of-completion measure, is appropriate where a court can confidently conclude that because the cost of remediation is much higher than the value of the remediation to the promisee, the promisee really doesn't want remediation. Instead the promisee really wants only money equal to the cost of performance, which he will then put in the bank rather than use to remediate. However, a special problem arises where prior to the breach the promisee explicitly or implicitly paid for the services that the promisor failed to perform.

For example, in Jacob \& Youngs, Inc. v. Kent, ${ }^{90}$ Jacob \& Youngs contracted to build a country house for Kent. The contract required the use of Reading brand cast-iron plumbing pipe..$^{91}$ After the house had been completed, Kent learned that Jacob \& Youngs had installed Cohoes cast-iron pipe instead of Reading pipe. Cohoes pipe was equal in quality, appearance, market value, and cost to Reading pipe-"indeed, the same thing, though manufactured in another place." ${ }^{, 92}$ Because the pipe was largely encased within the walls of the completed house, installation of Reading pipe in place of Cohoes presumably would have required a huge expenditure to demolish and reconstruct substantial parts of the house.

In these circumstances, cost-of-completion damages would be inappropriate, because it is clear that if Kent was awarded money damages in that amount, he would not use the money to tear down the new house and reconstruct an identical house with Reading pipe, but instead would put the money in the bank. However, because the two brands of pipe were identical, Kent's diminished-value damages would be zero. Since cost-of-completion damages would be inappropriate, and diminished-value damages would be zero, expectation damages would neither give Jacob \& Youngs the correct incentives to perform nor effectuate Kent's preference for Reading pipe, because Jacob \& Youngs could disregard that preference if the expectation measure was used. Furthermore, suppose that Reading pipe, although identical to Cohoes pipe, cost more. Presumably, the price that Kent paid for building the house would then have included a premium for the extra cost of Reading pipe. Unless contract law protected Kent's disgorgement interest by awarding Kent the cost that Jacob \& Youngs saved by using Cohoes pipe, Jacob \& Youngs would be unjustly enriched if it was allowed to retain the premium for Reading pipe, deliver Cohoes pipe, and not disgorge the premium. To give serviceproviders efficient incentives and to prevent unjust enrichment, the rule should be that where cost-of-completion damages are not awarded for breach by a service-provider, the promisee should have the right to require the service-provider to disgorge the costs she saved by her breach.

90. 129 N.E. 889 (N.Y. 1921).

91. Id. at 890 .

92. Id. 
The same point can be illustrated by considering a hypothetical variation of Peevyhouse v. Garland Coal \& Mining $\mathrm{Co}^{93}$ In the actual case, Willie and Lucille Peevyhouse leased a farm they owned to Garland Coal for a fiveyear period, during which Garland Coal would strip-mine the property. Garland Coal agreed, among other things, to perform restorative work at the end of the lease. Garland Coal stopped the strip-mining operation before it was completed, and then refused to perform the restorative work. The cost of restoration was thirty times the amount by which the restoration would increase the market value of the farm, and ten times market value of the farm if it was restored. The court held that Garland Coal was liable only for the diminished value of the farm.

Peevyhouse was incorrectly decided, because the court considered only the objective market value of the farm, not the subjective value of the farm to the Peevyhouses. In Ruxley Electronics \& Construction Ltd. v. Forsyth, the House of Lords held, in a comparable case, that the court should measure the promisee's subjective value directly. ${ }^{94}$ In most cases, however, the better alternative is for the court to determine whether the promisor has made a convincing case that the promisee would be highly unlikely to use an award based on the cost of completion to actually remediate the defective performance. Unless the court is convinced that the promisee would not do so, damages should be measured in the normal way, that is, by the cost of completion.

Because the farm in Peevyhouse apparently was a family farm, it is unlikely that Garland Coal could have convincingly shown that Peevyhouse was unlikely to use cost-of-completion damages to restore the land. ${ }^{95}$ Suppose, however, that the farm had been owned by Peevyhouse Agribusiness Corporation, a large Chicago-based corporation, which owned a large number of farms scattered through the Midwest. In that event, use of the diminished-value measure would have been correct, because if the cost of restoring the farm was ten times the value of the farm as restored, it is clear that Peevyhouse Agribusiness would not have used an award of damages in the amount of that cost to actually restore the farm, but instead would have either put the award in the bank or purchased ten comparable farms.

However, if in the Agribusiness hypothetical, as in the actual Peevyhouse case, Garland Coal was not required to pay damages based on the cost of restoration at the time of breach, it should at least be required to disgorge the expected cost of restoration at the time the contract was made, because Garland Coal must have reduced the price it paid for coal by that amount. At the time it made a strip-mining contract, Garland Coal must have been willing to pay the landowner a royalty-say, $\$ \mathrm{X}$ per ton-for every ton of coal it mined. If a landowner also wanted restoration, and Garland Coal agreed, then either (i) Garland Coal would make a flat upfront payment that the

93. 382 P.2d 109 (Okl. 1962).

94. (1995) 3 All E.R. 268 (U.K.H.L.).

95. Peevyhouse, 382 P.2d at 111. 
landowner could use for restoration, and correspondingly would reduce the per-ton royalty by the amount of the flat sum prorated over the number of tons it expected to mine, say, \$Y per ton; or (ii) Garland Coal would promise to make restoration itself, and would reduce royalties by the same amount. ${ }^{96}$ In Peevyhouse, the parties chose the latter alternative. Therefore, Garland Coal must have paid Peevyhouse $\$ \mathrm{X}-\$ Y$ per ton, rather than $\$ \mathrm{X}$ per ton, for each ton it mined. But since Garland Coal didn't do the restoration work, to give Garland the correct incentives to perform, and to prevent unjust enrichment, at a minimum Garland should have been required to disgorge an amount equal to $\$ Y$ per ton times the number of tons mined.

In the kinds of cases considered in this Section, the clearest for protection of the disgorgement interest are those in which the promisee has paid the cost of the services in advance and wants disgorgement of part of that payment. However, disgorgement should also be required where the promisee has paid for services indirectly, as in the Peevyhouse Agribusiness hypothetical, or where the promisor brings suit for expectation damages, notwithstanding her breach, under the doctrine of substantial performance, and the promisee claims a deduction for the cost of unperformed or improperly performed services that did not reduce the value of the promisor's performance. For example, in Samson \& Samson Ltd. v. Proctor, ${ }^{97}$ a New Zealand case, a builder sued an owner for money owed under a construction contract. The owner counterclaimed that the contract was not performed in various respects, the most important of which was that the building's steel reinforcing was insufficient. The builder responded that the owner had suffered no loss from the breach, because a few months after occupying the property, the owner sold the building for the price that he would have been paid if there had been no defects. The court properly held that the builder's response was irrelevant, and that the owner was entitled to deduct from the contract price the amount the builder saved by not fully performing the contract.

Normally, in cases in which disgorgement should be awarded based on the costs the promisor saved as a result of breach, disgorgement is an alternative, not a supplement, to diminished-value damages. For example, in Jacob \& Youngs v. Kent, Kent should have been able to recover either the difference between the value of his home with Cohoes pipe and the value of his home

96. Judith Maute reports that under the standard strip-mining lease used in the area in which the Peevyhouse farm was located, mining companies typically made a per-acre payment up front to compensate land owners for the damage that would be done to their land. Usually, this payment would equal the total value of the land before mining began. The Peevyhouses were aware of this standard arrangement, but they instead obtained Garland Coal's agreement to restore their land, because over the years they had seen the damage done to their neighbors' land. Judith L. Maute, Peevyhouse v. Garland Coal \& Mining Co. Revisited: The Ballad of Willie and Lucille, 89 Nw. U. L. REv. 1341 (1995).

97. [1974] 1 N.Z.L.R. 655 (S.C.); see also Healy v. Fallon, 37 A. 495 (Conn. 1897) (awarding to the owner the difference between the cost of the boards required by the contract and the cost of the boards used by the contractor); Farrington v. Freeman, 99 N.W.2d 388 (Iowa 1959) (awarding the difference between the cost of the windows required by the contract and the cost of the windows that the contractor installed). 
with Reading pipe, or the difference in cost between Cohoes and Reading pipe, but not both, because the two damage measures would overlap or even duplicate. ${ }^{98}$ Similarly, in the Peevyhouse Agribusiness hypothetical, Peevyhouse Agribusiness should not be awarded both diminished-value damages and disgorgement of Garland Coal's saved costs, because if those costs had been invested by Garland in restoring the farm, the diminution in the value of the farm would have been significantly reduced.

\section{Why Don't We See More Disgorgement in Contract LaW?}

The question might be asked, if disgorgement should be and is an available remedy in contract law, why don't we see more of it?

There are several answers to that question. In some cases, the courts may incorrectly believe themselves compelled by precedent not to grant disgorgement, but there are a number of other, more likely reasons, all of which are consistent with protection of the disgorgement interest.

To begin with, disgorgement, like specific performance, is a secondary rather than a primary remedy. The primary interest that should be and is protected by contract law is the expectation interest, and that interest is normally best protected by the expectation measure. The disgorgement interest should be protected primarily in those categories of cases in which such protection is required to provide efficient incentives to the promisor, to effectuate the contract, or to prevent unjust enrichment.

Furthermore, in many cases of breach there is no gain to be disgorged. For example, there may be no gain to be disgorged where the breach is inadvertent or results from circumstances that are beyond the seller's control. Even where a breach seems to involve a gain to the promisor, the gain may not result from, or be made possible, by the breach. For example, suppose Contractor A breaches a construction contract with Owner B, and then enters into another contract with Owner C. Most contractors can take on more than one job at a time. Therefore, it will be unlikely that A's gain from her contract with $\mathrm{C}$ will result from or be made possible by her breach of the contract with $\mathrm{B}$.

Next, in wide classes of cases protection of the disgorgement interest is unnecessary. In many cases, disgorgement will be less than expectation

98. 129 N.E. 889 (1921). Shawn Bayern has illustrated this point as follows:

To explain this idea, imagine a variation on Jacobs \& Youngs in which the amount the promisor saves by breaching equals the diminished value to the promisor; for instance, suppose that Reading pipes cost $\$ 5000$, Cohoes pipes cost $\$ 4000$, and the house is worth $\$ 1000$ more with Reading pipes than Cohoes pipes. (However, continue to suppose that [it would] cost substantially more-say $\$ 50,000$ - to replace the pipes.) In this case, the promisor gains $\$ 1000$ from breach and the promisee loses $\$ 1000$ from breach; the appropriate remedy seems to be a transfer of $\$ 1000$, not separate damages for loss and disgorgement for gain.

Now, suppose that the owner's diminished value in this variation of Jacobs \& Youngs were instead $\$ 500$. Still, disgorgement seems appropriate, but the total payment should still be $\$ 1000-$ right? (That is, just disgorgement-not disgorgement plus diminished value.) And if the owner's diminished value were $\$ 2000$, no separate disgorgement would be necessary.

Communication from Shawn Bayem to author (Apr. 19, 2005) (on file with Michigan Law Review). 
damages, so that the plaintiff will not seek protection of the disgorgement interest. In many other cases, disgorgement and expectation damages will be equal, so that after the promisor pays expectation damages she will have no gain left to disgorge. For example, in many cases that potentially raise the issue of disgorgement, a seller who has contracted to sell a given commodity to a buyer breaches the contract in order to resell the commodity to an overbidder. Disgorgement is unnecessary in such cases when the relevant commodity is homogeneous and not in critically short supply. If a commodity is homogeneous and not in critically short supply, an overbidder will not pay the seller more for the commodity than the market price. Why should he, when he can purchase the commodity on the market for that price? Accordingly, in such a case the seller's gain on a sale to an overbidder will be the difference between the market price at the time of breach and the contract price to the original buyer. That difference, however, is also the measure of the buyer's expectation damages. Accordingly, after the seller pays expectation damages, she will have no gain remaining to be disgorged.

Suppose the relevant commodity is differentiated rather than homogeneous. Even then, in the Overbidder Paradigm disgorgement is unnecessary unless the price paid by the overbidder exceeds the market price of the commodity. Since the buyer can always recover the difference between the market price and the contract price, if the overbidder pays no more than the market price, the buyer would get no more from disgorgement than he would get from expectation damages. ${ }^{99}$

Disgorgement will also be unnecessary where the promisee obtains specific performance, because that remedy will prevent the promisor from making a gain through breach.

Finally, disgorgement may be inappropriate in certain classes of cases for special moral or policy reasons. For example, disgorgement would be inappropriate in cases involving employees who breach employment contracts and then take higher-paying jobs, because requiring disgorgement in such cases would cut too close to the bone of involuntary servitude. ${ }^{100}$

99. The two measures will, however, sometimes diverge in such cases. In the case of a differentiated commodity, "market price" is normally a construct based on extrapolation from the prices paid in comparable but not identical transactions. Accordingly, the expectation and disgorgement measures may diverge in overbidder cases because the price paid by the overbidder exceeds the constructed market price, due to the dynamics of the negotiation between the seller and the overbidder, or because the overbidder was not well-informed, or had a special strategic need for the property, or was willing to pay at the top end of the range of comparable transactions, while the construct falls in the mid-range. And under the law of many states, a seller of real estate is not liable for expectation damages if her breach is not in bad faith. On these issues, see 1 PALMER, supra note 5, § 4.9 .

100. Cf. Friedmann, supra note 55 , at 520 (noting that the courts are usually unwilling to order specific performance of an employment contract because it would "conflict with the basic concern that persons not be compelled to perform contracts for personal services against their will .... [In the absence of exceptional circumstances, the] same concern may also protect the employee from any claim by his former employer to the additional income he receives from his new work, at least where recognition of such claims would create undesirable impediments to social and economic mobility."); S.M. Waddams, Profits Derived From Breach of Contract: Damages or Restitution, 11 J. ConTRACT LAW 115, 119 (1997) (arguing that to permit an employer to recover 
In short, in most cases either there is no gain to be disgorged, disgorgement is unnecessary, or disgorgement is inappropriate for special moral or policy reasons. This, and not the unavailability of disgorgement under modern law, is the major reason why we don't see more of it.

\section{The Problem of Apportionment}

In some cases in which the remedy of disgorgement is appropriate, a portion of the amount that is subject to being disgorged is a product of the promisor's skill and diligence. In such cases, the question arises whether the amount that would otherwise be disgorged should be apportioned between the promisor and the promisee. ${ }^{101}$

In many cases, apportionment is not an issue. This will be true, for example, where the promisor's gains from breach are not the result of her skill and diligence, or where disgorgement is based on the promisor's skimped costs.

In other cases, apportionment would be inappropriate because it would nullify the reason for disgorgement. For example, in United States v. Snepp, Snepp had breached his contract by failing to obtain the CIA's consent to publication of his book. ${ }^{102}$ Given the Government's reason for requiring Snepp to obtain consent, disgorgement of Snepp's royalties was necessary to effectuate the contract. If the Court had ordered apportionment to account for the percentage of the royalties that resulted from Snepp's efforts, the disgorgement remedy would have been virtually nullified, partly because the value of those efforts probably approached or equaled the total amount of the royalties, and partly because Snepp's very wrong was to use his efforts to write the book.

In most of the remaining disgorgement cases, apportionment can best be approached by asking whether, if disgorgement in full were hypothetically awarded, a failure to return part of the disgorged amount to the promisor would leave the promisee with an undue windfall. In most cases, the answer to this question would be no. In cases that fall within the Overbidder Paradigm, for example, the buyer would not get an undue windfall as a result of not paying the seller for its efforts to find the overbidder, because the buyer paid the seller a premium not to engage in those efforts. In cases like Snepp and Blake, the Governments did not get undue windfalls, because they were simply recapturing an illicit gain. ${ }^{103}$

disgorgement of an employee's profit from breaking an employment contract "would be to give the employer a sort of proprietary interest in the employee's services: this concept is unacceptable.").

101. For an important treatment of apportionment in the law of unjust enrichment generally, see Friedmann, Restitution for Wrongs, supra note 56, at 1899-1903.

102. 444 U.S. 507,507 (1980).

103. Cf. SEC v. JT Wallenbrock \& Assoc., 440 F.3d 1109 (9th Cir. 2006). The defendants had defrauded investors by engaging in a Ponzi scheme. In a suit for disgorgement of the amount of the investments, the defendants sought to offset, against that amount, the expenses of running the business. The Ninth Circuit said, "[I]t would be unjust to permit the defendants to offset against the investor dollars they received the expenses of running the very business they created to defraud those investors into giving the defendants the money in the first place." Id. at 1114. 
In general, there should be a heavy thumb on the scale against apportionment because usually apportionment would either undercut disgorgement or be otherwise inappropriate. Therefore, where disgorgement is awarded, the promisor should have the burden of proving that apportionment should be made. However, there may be a few cases in which the promisor can shoulder that burden. For example, in EarthInfo, Inc. v. Hydrosphere Resource Consultants, Inc., Hydrosphere had made a series of contracts with EarthInfo. ${ }^{104}$ Under the contracts, Hydrosphere agreed to develop hydrological and meteorological CD-ROMs and software. EarthInfo, in turn, would prepare users' manuals for the CD-ROMs, package and market the CD-ROMs and the manuals, and pay Hydrosphere a fixed hourly development fee, as well as royalties on new products. The contracts vested all copyright, patent, and other ownership rights in EarthInfo.

In June 1990, Hydrosphere and EarthInfo became embroiled in a dispute over whether EarthInfo owed royalties to Hydrosphere on certain products. On June 30, pending resolution of the dispute, EarthInfo suspended payment of royalties that it admittedly owed. In response, in December 1990, Hydrosphere notified EarthInfo that it was rescinding the contracts, and brought suit for rescission and restitution.

The trial court determined as follows: EarthInfo's suspension of royalties was a substantial breach. Due to the nature of the contracts, and the depth of the parties' dispute, the appropriate remedy was rescission and restitution. The court set June 30,1990, as the date of rescission, and ordered EarthInfo to return to Hydrosphere all tangible property that it had developed under the contracts. In addition, the court required EarthInfo to disgorge the net profits that it had realized on sales of the CD-ROMs after June 30 .

The Colorado Supreme Court affirmed most of the trial court's decision. It held that there is no rule that disgorgement is unavailable as a remedy for breach of contract. Instead, the rule is that the courts have power to award disgorgement in appropriate cases. In EarthInfo itself, the court held, disgorgement was appropriate because the breach was conscious and substantial. ${ }^{105}$ However, the court went on to hold, the trial court erred in

104. 900 P.2d 113 (Colo. 1995) (en banc). More accurately, Hydrosphere had made a series of contracts with EarthInfo's predecessor in interest. For ease of exposition, I will use the term "EarthInfo" to mean both EarthInfo and its predecessor.

105. The apparent requirement in EarthInfo that the breach be conscious is inappropriate. For example, in Coppola Enterprises v. Alfone, 531 So. 2d 334 (Fla. 1988), where a vendor resold a home to an overbidder, the Florida Supreme Court properly held that the original buyer was entitled to disgorgement whether or not the vendor had acted in bad faith.

A requirement similar to that of EarthInfo is inappropriately proposed in Section 39(1) of the RESTATEMENT (THIRD) OF Restitution $\S 39$ (tentative draft No. 5), which would permit disgorgement for breach of contract, but only if the breach is deliberate. Significantly, some of the Illustrations to section 39 are inconsistent with the black letter. Illustration 14 is particularly striking in this regard:

Builder and Owner agree on the construction of a house at a price of $\$ 2$ million. The specifications call for foundations to be made of Vermont granite, and the work has been bid and priced on that basis. By mistake and inadvertence, builder constructs the foundations of granite quarried in New Hampshire. This fact comes to light when construction has been completed. The 
failing to apportion the net profits in a way that reflected the relative contributions to those profits by the parties:

The record in this case indicates that EarthInfo materially contributed effort and investment to the Hydrodata line of products. EarthInfo's contribution included user manuals, packaging, trademarks, promotional materials, and lists of persons or entities licensed to use the products. Thus, EarthInfo should be credited for the amount of its expenses in developing and marketing the Hydrodata product line. ${ }^{106}$

This apportionment was correct. EarthInfo's contributions to the gain were not in themselves wrongful; on the contrary, those contributions were contractually required. Hydrosphere therefore would have reaped an undue windfall if it was allowed to retain all the fruits of EarthInfo's efforts.

\section{CONCLUSION}

It has traditionally been assumed that the disgorgement interest is not protected by contract law, despite the availability of disgorgement in other areas of private law. This assumption is reflected in Restatement Second section 344 , which excludes disgorgement from the interests protected by judicial remedies for breach of contract. However, the traditional assumption is not compelled by the case law and lacks normative support. Of course, the disgorgement interest should not be protected in all cases in which a promise is legally enforceable, any more than the reliance interest, the restitution interest, or, for that matter, the expectation interest are protected in all cases. Rather, as in the case of those interests, the disgorgement interest should be protected when appropriate. In certain classes of cases such protection is almost always appropriate-in particular, where disgorgement has been bargained for, or is the best or only way to provide efficient incentives for precaution and performance and to effectuate contracts, or to prevent unjust enrichment.

The assumption that contract law does not protect the disgorgement interest is comparable to the assumption of the classical school of contract law that contract law did not protect the reliance interest. This assumption was reflected in the First Restatement of Contracts. Section 326 of that Restatement recognized only three remedies for breach of contract: (1) "damages,"

\footnotetext{
difference in the appraised value of Owner's property as a result of the nonconformity is nil. The cost to cure the default would far exceed the total price of the house. Because New Hampshire granite is less expensive than comparable stone from Vermont, Builder has saved $\$ 15,000$ as a result of his negligent breach of contract. Owner may recover damages of $\$ 15,000$ for builder's breach ....
}

This Illustration squarely contradicts-as it should-the text of section 39. The contradiction is admitted, and then "explained," as follows: "The case is not within the rule of $\S 39$ (because Builder's default is unintentional), but principles of unjust enrichment reinforce the conclusion that saved expenditure makes an appropriate measure of contract damages in such a case." Id. $\S 39$. But this explanation only underlines the defects in section 39. If disgorgement for breach of contract should be allowed outside the limit of section 39 (as it is and should be) then the artificial limit of section 39 serves no function (as it doesn't and shouldn't).

106. Earthlnfo., 900 P.2d at 121. 
which, as shown by the text of section 326 and the comment, meant only expectation damages; (2) restitution, which, as shown by section 347 ("Restitution of Value of Performance Rendered By One Party"), meant only benefit conferred; and (3) specific performance. ${ }^{107}$ Under section 326 , therefore, the reliance interest was excluded from the interests protected by contract law. ${ }^{108}$ However, as Fuller and Perdue showed in their landmark article The Reliance Interest in Contract Damages, ${ }^{109}$ that position had little support in the case law and no normative support at all. Rather, that position, like so much of classical contract law, rested only on axiomatic grounds, and was properly discarded in Restatement Second. ${ }^{110}$ Most of the axioms of classical contract law now lie in the trash-heap of wrong ideas. The assumption that the disgorgement interest is not protected by contract law rests among the rubble of those axioms.

107. Restatement (First) of Contracts $\$ \$ 326,347$ (1932).

108. Id. § 326 .

109. L.L. Fuller \& William R. Perdue, Jr., The Reliance Interest in Contract Damages (pts. 1-2), 46 YAlE L.J. 52, 373 (1936-1937).

110. See, e.g., Proceedings at the Fourth Annual Meeting, 4 A.L.I. Proc. app. at 103-04 (1926) (remarks of Mr. Williston) ("Either the [relied-upon donative] promise is binding or it is not. If this promise is binding it has to be enforced as it is made [and not simply to the extent that it was relied upon] .... I could leave this whole thing to the subject of quasi contracts so that the promisee under those circumstances shall never recover on the promise but he shall recover such an amount as will fairly compensate him for any injury incurred; but it seems to me you have to take one leg or the other. You have either to say the promise is binding or you have to go on the theory of restoring the status quo."). 